\title{
The Chemistry of Sodium With Sulfur in Flames
}

\author{
Final Report
}

M. Steinberg

K. Schofield

February 1991

Work Performed Under Contract No.: DE-FG21-86MC23135

For

U.S. Department of Energy

Office of Fcssil Energy

Morgantown Energy Technology Center

Morgantown, West Virginia

By

University of Califomia

Quantum Institute

Santa Barbara, Califomia 


\section{DISCLAIMER}

This report was prepared as an account of work sponsored by an agency of the United States Government. Neither the United States Government nor any agency thereof. nor any of their employees, makes any warranty, express or implied, or assumes any legal liability or responsibility for the accuracy, completeness, or usefulness of any information, apparatus, product, or process disclosed. or represents that its use would not infringe privately owned rights. Reference herein to any specific commercial product, process. or service by trade name. trademark, manufacturer. or otherwise does not necessarily constitute or imply its endorsement, recommendation, or favoring by the United States Government or any agency thereof. The views and opinions of authors ex. pressed herein do not necessarily state or reflect those of the United States Government or any agency thereof.

This report has been reproduced directly from the best available copy.

Available to DOE and DOE contractors from the Office of Scientific and Technical Information, P.O. Box 62, Oak Ridge, TN 37831; prices available from (615)576-8401, FTS 626-8401.

Available to the public from the National Technical Information Service, U.S. Department of Commerce, 5285 Port Royal Rd., Springfield, VA 22161. 
The Chemistry of Sodium With Sulfur in Flames

Final Report

M. Steinberg

K. Schofield

Work Performed Under Contract No.: DE-FG21-86MC23135

\author{
For \\ U.S. Department of Energy \\ Office of Fossil Energy \\ Morgantown Energy Technology Center \\ P.O. Box 880 \\ Morgantown, West Virginia 26507-0880 \\ By \\ University of California \\ Quantum Institute \\ Santa Barbara, California 93106
}

February 1991 


\section{CONTENTS}

Page

List of Figures $\quad$ ii

List of Tables $\quad$ iii

$\begin{array}{lr}\text { 1. Abstract } & 1\end{array}$

2. Introduction $\quad 2$

3. Experimental Conditions $\quad 5$

$\begin{array}{lrr}\text { 4. } & \text { Results } & 8\end{array}$

5. Modeling Overview 10

6. Sodium/Sulfur Species Characterization 14

7. Kinetic Modeling 24

8. Discussion $\quad 36$

9. Conclusions $\quad 42$

10. References 44

11. Presentations and Publications $\quad 48$ 
1. Optical arrangement

2. Measured $(\mathrm{Na})$ and $(\mathrm{OH})$ downstream profiles in a lean $\mathrm{H}_{2} / \mathrm{O}_{2} / \mathrm{N}_{2}$ flame with varying amounts of $\mathrm{SO}_{2}$

3. Trace species profiles in a lean $\mathrm{H}_{2} / \mathrm{O}_{2} / \mathrm{N}_{2}=1.4 / 1 / 5$

flame in the presence of $1 \% \mathrm{SO}_{2}$ (solid lines) or sulfur free (broken lines)

4. Trace species profiles in a rich $\mathrm{H}_{2} / \mathrm{O}_{2} / \mathrm{N}_{2}=3 / 1 / 6$ flame in the presence of $1 \% \mathrm{H}_{2} \mathrm{~S}$ (solid lines) or sulfur free (broken lines)

5. Correlation of internuclear separation and dissociation energies for alkali metal compounds, $M X$, to their ions, $\mathrm{M}^{+}$and $\mathrm{X}^{-}$, or to $\mathrm{M}$ and $\mathrm{X}$ neutrals in the case of the six sodium/sulfur compounds

6. Sodium/sulfur reaction scheme. The reactions connecting $\mathrm{NaSH}, \mathrm{NaSO}_{2} \mathrm{NaS}$, and $\mathrm{NaS}_{2}$ with sodium and its oxides are not shown here to avoid complication

7. Comparison of measured and calculated sodium profiles in a lean $\mathrm{H}_{2} / \mathrm{O}_{2} / \mathrm{N}_{2}$ flame with varying amounts of $\mathrm{SO}_{2}$.

8. Comparison of measured and calculated sodium profiles in a rich $\mathrm{H}_{2} / \mathrm{O}_{2} / \mathrm{N}_{2}$ flame with varying amounts of $\mathrm{H}_{2} \mathrm{~S}$

9. Calculated sodium compound relative distribution profiles in a lean $\mathrm{H}_{2} / \mathrm{O}_{2} / \mathrm{N}_{2}$ flame with added $\mathrm{SO}_{2}$

10. Calculated sodium compound relative distribution profiles in a rich $\mathrm{H}_{2} / \mathrm{O}_{2} / \mathrm{N}_{2}$ flame with added $\mathrm{H}_{2} \mathrm{~S}$ 


\section{LIST OF TABLES}

Table

Page

1. Experimental Flame Matrix and Burnt Gas Properties

2. Molecular Properties of Flame Generated Sodium/Sulfur Compounds

3. Rate Constants Utilized in Modeling Sodium/Sulfur Flame Chemistry, in cm molecule s units

4. $\mathrm{Na}_{2} \mathrm{SO}_{4}(\mathrm{~g})$ Formation Estimates for a $\mathrm{H}_{2} / \mathrm{O}_{2} / \mathrm{N}_{2}=1.4 / 1 / 5$

Flame with $1 \% \mathrm{SO}_{2}$ 


\section{ABSTRACT}

An experimental and analytical program examining sodium/sulfur chemistry has been conducted in a series of fuel rich and lean $\mathrm{H}_{2} / \mathrm{O}_{2} / \mathrm{N}_{2}$ flames, with and without added sulfur, and covering a wide range of temperatures and stoichiometries. Fluorescence measurements of $\mathrm{OH}$ and $\mathrm{Na}$ downstream profiles and sodium line reversal temperatures provided a broad data base for kinetic modeling. Analysis indicated $\mathrm{NaSO}_{2}$ to be the only significant sodium/sulfur product formed in the lean flames. Even so, its concentrations remain an extremely small fraction of the total sodium. The more important perturbation of the distribution of sodium over its molecular forms results from the catalytic effect of sulfur on the flame radical concentration levels rather than the formation of additional species. A bond dissociation energy of $\mathrm{D}_{0}^{\circ}\left(\mathrm{Na}-\mathrm{SO}_{2}\right)=197 \pm 20 \mathrm{~kJ}$ $\mathrm{mol}^{-1}$ is derived assuming a non-planar structure or $210 \pm 20 \mathrm{~kJ} \mathrm{~mol}^{-1}$ if the molecule is planar. $\mathrm{NaOS}$ is dominant in the rich flames, coupled with small contributions from $\mathrm{NaSO}_{2}, \mathrm{NaSH}, \mathrm{NaS}$, and $\mathrm{NaS}_{2}$. Together, these can constitute from about 10 to $20 \%$ of the total flame sodium and do represent in this case an enhancement of molecular formation. Preliminary data in fuel rich $\mathrm{C}_{2} \mathrm{H}_{2} / \mathrm{O}_{2} / \mathrm{N}_{2}$ flames are consistent with this model. This further illustrates the general insensitivity of alkali chemistry to fuel type.

Analyses based on results developed in the study find $\mathrm{Na}_{2} \mathrm{SO}_{4}$ formation is kinetically limited and cannot be a significant gas phase flame product at sodium levels much below $100 \mathrm{ppm}$. $\mathrm{Na}_{2} \mathrm{SO}_{4}$ induced corrosion in combustion systems must result from heterogeneously formed $\mathrm{Na}_{2} \mathrm{SO}_{4}$. When the present results are coupled to those of deposition studies, it is possible to speculate that one of the more likely mechanisms could involve gas phase $\mathrm{NaO}_{2}$ condensing and reacting with $\mathrm{SO}_{2}$ on the surface to ultimately 
produce $\mathrm{Na}_{2} \mathrm{SO}_{4}$.

\section{INTRODUCTION}

Sodium sulfate was identified 45 years ago as a serious corrosive agent in the ash deposits on power plant boiler tubes. ${ }^{1}$ Subsequently, the surprising corrosive character of sodium sulfate also was noted in deposits on oxidation resistant turbine alloys in combustion driven gas turbines. ${ }^{23}$ Whether it is formed through homogeneous gas phase chemistry in the combustion gases or is produced heterogeneously on the surfaces has remained an unanswered question. There is no chemical kinetic information for modeling this aspect of the problem. Consequently past efforts to analyze the gas/surface interactions have been forced to invoke limiting conditions of frozen chemistry or chemical equilibrium for the sodium/sulfur system. ${ }^{45}$

Although an extensive literature has developed concerning sodium sulfate in combustion systems, only a few efforts have been made to understand the underlying sodium/sulfur flame chemistry. Fenimore ${ }^{6}$ reported a decrease of $\mathrm{Na}$ with the addition of $\mathrm{SO}_{2}$ to rich and lean $\mathrm{H}_{2}$ /Air flames. He assumed the flame chemistry to be fully equilibrated and attributed the sodium decay to reaction (1).

$$
\mathrm{NaOH}+\mathrm{SO}_{2}=\mathrm{NaSO}_{2}+\mathrm{OH}
$$

By further supposing that the sodium was distributed solely between its $\mathrm{Na}, \mathrm{NaOH}$ and $\mathrm{NaSO}_{2}$ forms he derived an equilibrium constant value of $\mathrm{K}_{1}=5 \exp \left(-71 \mathrm{~kJ} \mathrm{~mol}^{-1} / \mathrm{RT}\right)$. Durie et al., 7 in a study in rich and lean $\mathrm{C}_{3} \mathrm{H}_{8} / \mathrm{O}_{2} / \mathrm{N}_{2}$ flames, assigned instead the corresponding sodium decays to the equilibration of reactions (2) and (3), respectively 


$$
\begin{gathered}
\mathrm{NaOH}+\mathrm{S}=\mathrm{NaS}+\mathrm{OH} \\
\mathrm{NaOH}+\mathrm{SO}_{3}=\mathrm{NaSO}_{3}+\mathrm{OH}
\end{gathered}
$$

and derived equilibrium constants $\mathrm{K}_{2}=8 \times 10^{5} \exp \left(-243 \mathrm{~kJ} \mathrm{~mol}^{-1} / \mathrm{RT}\right)$ and $\mathrm{K}_{3}=2 \times 10^{6} \exp (-172$ $\mathrm{kJ} \mathrm{mol}^{-1} / \mathrm{RT}$ ). The flame chemistry in this study was also assumed to be fully equilibrated. They felt that Fenimore's lean flame data was better correlated by reaction (3) than by reaction (1). Fryb. $\mathrm{rg}$ et al. ${ }^{4}$ identified $\mathrm{NaSO}_{2}, \mathrm{NaSO}_{3}$, and $\mathrm{Na}_{2} \mathrm{SO}_{4}$ as gas phase products in a mass spectrometric study of lean $\mathrm{CH}_{4} / \mathrm{O}_{2}$ flames seeded very heavily with sodium and sulfur. They reported clogging of the sample inlet orifice which limited data gathering and interpretation. Thus it is not possible to conclude whether the observed species are in fact homogeneous gas phase flame products.

The current study is an extension of two earlier investigations in this laboratory, the first on sulfur chemistry ${ }^{8}$ in rich $\mathrm{H}_{2} / \mathrm{O}_{2} / \mathrm{N}_{2}$ flames and the other considering sodium oxidation chemistry9,10 in lean $\mathrm{H}_{2} / \mathrm{O}_{2} / \mathrm{N}_{2}$ flames. The conclusions of each of these now have been confirmed elsewhere. ${ }^{11-13}$

It is well established that the radicals $\mathrm{H}, \mathrm{O}$, and $\mathrm{OH}$ in the hot burnt gases of $\mathrm{H}_{2} / \mathrm{O}_{2} / \mathrm{N}_{2}$ flames can sharply overshoot their equilibrium levels through rapid bimolecular chain reactions (4-6) which are balanced (equilibrated due to their large kinetic fluxes in an otherwise non-equilibrated flame environment).

$$
\begin{aligned}
\mathrm{H}+\mathrm{O}_{2} & =\mathrm{OH}+\mathrm{O} \\
\mathrm{O}+\mathrm{H}_{2} & =\mathrm{OH}+\mathrm{H} \\
\mathrm{H}_{2}+\mathrm{OH} & =\mathrm{H}_{2} \mathrm{O}+\mathrm{H}
\end{aligned}
$$

From measures of $\mathrm{OH}$, temperature, the overall flame stoichiometry, and the equilibrium constants for reactions (4-6), the non-equilibrium concentrations of $\mathrm{H}, \mathrm{O}, \mathrm{H}_{2}, \mathrm{O}_{2}$, and 
$\mathrm{H}_{2} \mathrm{O}$ in rich and lean flames are calculable, using such partial equilibrium concepts. The radicals recombine through relatively slow 3-body reactions $(\mathrm{H}+\mathrm{H}, \mathrm{O}+\mathrm{O}, \mathrm{H}+\mathrm{OH}$, and $\mathrm{H}+\mathrm{O}_{2}$ ). With the addition of sulfur to these flames, radical recombination is catalyzed ${ }^{14-16}$ and in turn the decaying radical concentrations control the partial equilibrium balances known to exist between $\mathrm{SO}_{3}, \mathrm{SO}_{2}, \mathrm{SO}, \mathrm{H}_{2} \mathrm{~S}, \mathrm{SH}, \mathrm{S}_{2}$ and S. ${ }^{8}$ As with the flame radicals, the concentrations of these sulfur species are coupled and can be calculated from measured $\mathrm{OH}$, temperature, total sulfur content, and the equilibrium constants for the appropriate coupling reactions. $\mathrm{SO}_{3}$ is exceptional, being formed only by a slow termolecular reaction ${ }^{17,18}$ and its concentration can be assumed to be in steady state through reactions $(7-9)$.

$$
\begin{aligned}
\mathrm{SO}_{2}+\mathrm{O}+\mathrm{M} & =\mathrm{SO}_{3}+\mathrm{M} \\
\mathrm{SO}_{3}+\mathrm{O} & =\mathrm{SO}_{2}+\mathrm{O}_{2} \\
\mathrm{SO}_{3}+\mathrm{H} & =\mathrm{SO}_{2}+\mathrm{OH}
\end{aligned}
$$

The oxidation of sodium in fuel-lean, sulfur free, $\mathrm{H}_{2} / \mathrm{O}_{2} / \mathrm{N}_{2}$ flames was found to exhibit an interesting chemistry.,10 The performance of the total model, consisting of seventeen possible reactions, is approximated by reactions (10) through (14).

$$
\begin{gathered}
\mathrm{Na}+\mathrm{O}_{2}+\mathrm{M}=\mathrm{NaO}_{2}+\mathrm{M} \\
\mathrm{NaO}_{2}+\mathrm{OH}=\mathrm{NaOH}+\mathrm{O}_{2} \\
\mathrm{NaO}_{2}+\mathrm{H}=\mathrm{NaO}+\mathrm{OH} \\
\mathrm{NaO}+\mathrm{H}_{2} \mathrm{O}=\mathrm{NaOH}+\mathrm{OH} \\
\mathrm{Na}+\mathrm{H}_{2} \mathrm{O}=\mathrm{NaOH}+\mathrm{H}
\end{gathered}
$$

The dominant oxidation path occurs through a surprisingly fast 3-body process, reaction (10), the kinetic nature of which is now well established. ${ }^{1924}$ The $\mathrm{NaO}_{2}$ reacts with the 
radicals, $\mathrm{H}$ and $\mathrm{OH}$, and can produce a very large overshoot in $\mathrm{NaOH}$ concentrations, which are balanced with small amounts of $\mathrm{NaO}$ in the very fast reaction (13). The free sodium profiles closely track the $\mathrm{H}$-atom profiles in the lean flames. This is mainly a consequence of the low $\mathrm{H}$-atom concentrations in these flames limiting the conversion of $\mathrm{NaOH}$ back to $\mathrm{Na}$ via reaction (14) and is the major factor in controlling the overshoots of the $\mathrm{NaOH}$. In rich flames reaction (10) is negligible and sodium oxidation is slight, controlled predominantly by reaction (14). Based on this information, the concentration profiles for $\mathrm{Na}, \mathrm{NaO}_{2}, \mathrm{NaOH}$, and $\mathrm{NaO}$ in the sulfur free flames can now be calculated from measured $\mathrm{OH}$, temperature, flame stoichiometry, and the total sodium concentration.

The complementary nature of the rich and lean flame systems is of great value to this study. In lean flames, whereas the sodium chemistry is complex that of the sulfur is quite simple, and under rich conditions exactly the opposite is found. When the two are present simultaneously, the possible sodium/sulfur chemistry is superimposed on their individually complex yet reasonably well understood systems. What is found is that sodium sulfidation chemistry competes with sodium oxidation but both are seen to be heavily influenced, if not controlled, by the flame radicals and the radical/sulfur chemistry interaction. Although potentially very complex, as will be seen, the system has been amenable to a reasonable analysis.

\section{EXPERIMENTAL CONDITIONS}

Measurements are made in the laminar, premixed, one dimensional flow of the post flame gases above a Padley-Sugden ${ }^{25}$ burner of bundled hypodermic tubing with an overali diameter of $2.2 \mathrm{~cm}$. Sodium is introduced as an aqueous $\mathrm{NaNO}_{3}$ aerosol generated 
in an ultrasonic nebulizer ${ }^{26}$ and transported by a portion of the gas flow to a $1.1 \mathrm{~cm}$ diameter central core of the burner. Sulfur is added as $\mathrm{H}_{2} \mathrm{~S}$ to rich, and $\mathrm{SO}_{2}$ to lean flames to minimize thermal contributions these additives make to flame properties. Except for the small change in stoichiometry and the accompanying thermal effect, the additions of $\mathrm{H}_{2} \mathrm{~S}$ or $\mathrm{SO}_{2}$ to a given $\mathrm{H}_{2} / \mathrm{O}_{2} / \mathrm{N}_{2}$ flame are equivalent sources of sulfur yielding approximately the same distribution of sulfur among the species, $\mathrm{SO}_{3}, \mathrm{SO}_{2}, \mathrm{SO}, \mathrm{H}_{2} \mathrm{~S}, \mathrm{SH}, \mathrm{S}_{2}$, and $\mathrm{S}^{8}$ The central burner core is surrounded by an annular shield section which burns the same basic flame but without added sodium or sulfur. A schematic of the optical system is shown in Figure 1. Temperatures are determined by using the sodium line reversal method. Sodium and $\mathrm{OH}$ concentrations are measured by laser induced fluorescence $e^{8,2,28}$ utilizing a YAG pumped dye laser source beam passed through the flame parallel to the burner surface. The fluorescence, from a slice of the laser excited flame volume at flame center, is collected by a 6-inch mirror and focused with unit magnification through an image rotator into the vertical entrance slit of the monochromator. The burner is mounted on a motor driven table programmed to collect data as a function of distance (and time) above the burner surface. The monochromator output is detected with a photomultiplier, the signal amplified, processed in a boxcar integrator, and recorded.

The sodium $589.0 \mathrm{~nm}$ transition was pumped and the fluorescence detected via the collisionally coupled $589.6 \mathrm{~nm}$ transition. Saturation excitation was employed to eliminate quenching uncertainties which may be significant for atomic species. The $\mathrm{OH}\left(\mathrm{A}^{2} \Sigma^{+}-\mathrm{X}^{2} \Pi\right)$ $(1,0), R_{1}(6)$ transition at $281.14 \mathrm{~nm}$ was excited and fluorescence detected at $314.69 \mathrm{~nm}$ from the $(1,1), Q_{1}(7)$ transition. The previously validated $\mathrm{OH}$ measurements are absolute 


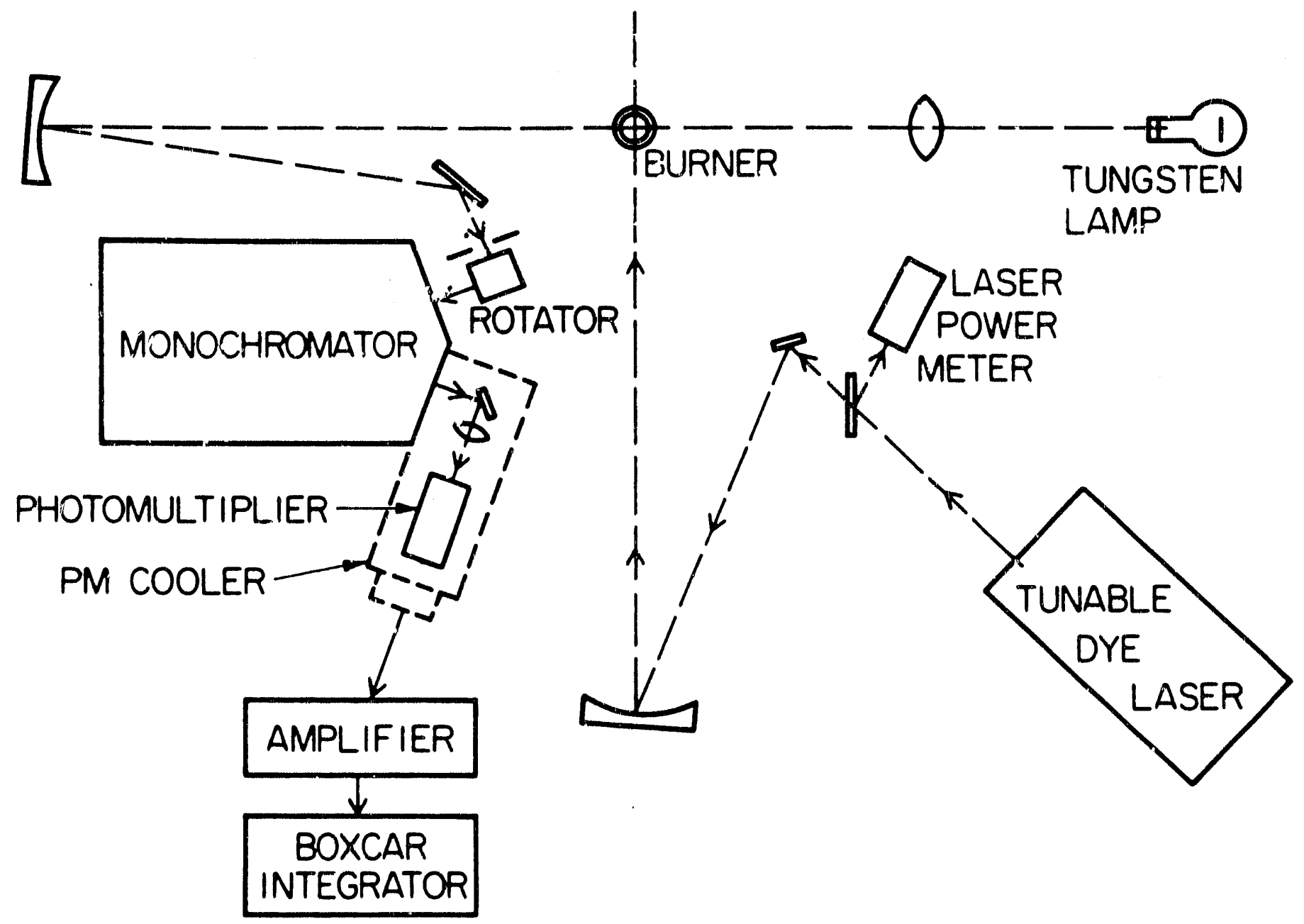

Figure 1. Optical arrangement. 
values calibrated against a high temperature flame $\left(\mathrm{H}_{2} / \mathrm{O}_{2} / \mathrm{N}_{2}=4 / 1 / 2, \mathrm{~T}=2500 \mathrm{~K}\right)$ in which $\mathrm{OH}$ is at thermodynamical equilibrium. ${ }^{28}$

\section{RESULTS}

Measurements have been made in 19 lean and rich $\mathrm{H}_{2} / \mathrm{O}_{2} / \mathrm{N}_{2}$ flames containing sodium with and without added sulfur. The flame matrix is listed in Table 1. Measured (Na) and $(\mathrm{OH})$ concentration profiles are plotted for a lean flame in Figure 2. The sodium experimental data have been scaled to refer to the same amount of total sodium in each

Table 1. Experimental flame matrix and burnt gas properties

\begin{tabular}{|c|c|c|c|c|c|}
\hline $\mathrm{H}_{2} / \mathrm{O}_{2} / \mathrm{N}_{2}$ & $\begin{array}{l}\text { Temperature } \\
\text { (K) }\end{array}$ & {$\left[\mathrm{H}_{2} \mathrm{O}\right]$} & \multicolumn{2}{|c|}{$\underset{\left(\text { molecules } / \mathrm{cm}^{3} \text { ) }\right.}{\left[\mathrm{O}_{2}\right]}$} & {$[\mathrm{OH}]$} \\
\hline $0.6 / 1 / 1$ & $1906-1929$ & $1.0(18)$ & $1.2(18)$ & $\cdots$ & $3.8->0.7(16)^{\Delta}$ \\
\hline $1 / 1 / 2$ & $2066-2100$ & $9.9(17)$ & 4.8(17) & -.. & $3.8->1.1(16)$ \\
\hline $1 / 1 / 3$ & $1667-1730$ & $9.5(17)$ & $4.7(17)$ & $\cdots$ & $3.7->0.3(16)$ \\
\hline $1.4 / 1 / 3$ & $2125-2197$ & $9.8(17)$ & $2.0(17)$ &.-- & $3.5->1.4(16)$ \\
\hline $1.4 / 1 / 4$ & $1810-1847$ & $9.8(17)$ & $2.1(17)$ & -.. & $3.6->0.5(16)$ \\
\hline $1.4 / 1 / 5$ & $1654-1669$ & $9.3(17)$ & $2.0(17)$ & $-\cdots$ & $3.6->0.3(16)$ \\
\hline $1.8 / 1 / 3$ & $2280-2405$ & $1.1(18)$ & $5.9(16)$ & -- & $4.0->1.9(16)$ \\
\hline $1.8 / 1 / 4$ & $2060-2228$ & $9.8(17)$ & $5.1(16)$ & $\cdots$ & $3.6->1.4(16)$ \\
\hline $1.8 / 1 / 5$ & $1825-1916$ & $1.0(18)$ & $5.3(16)$ & $\cdots$ & $3.2->0.7(16)$ \\
\hline $1.8 / 1 / 6$ & $1695-1726$ & $9.6(17)$ & $5.2(16)$ & $\ldots$ & $3.1->0.4(16)$ \\
\hline $2.2 / 1 / 4$ & $2160-2308$ & $1.0(18)$ & $\ldots$ & $1.1(17)$ & $3.8->1.3(16)$ \\
\hline $2.2 / 1 / 5$ & $1975-2106$ & $9.7(17)$ & $\ldots$ & $9.8(16)$ & $2.7 \cdot>0.8(16)$ \\
\hline $2.2 / 1 / 6$ & $1780-1897$ & $0.4(17)$ & $\cdots$ & $9.6(16)$ & $1.9->0.5(16)$ \\
\hline $3 / 1 / 4$ & $2050-2167$ & $9.7(17)$ & $\ldots$ & $4.8(17)$ & $2.4->0.3(16)$ \\
\hline $3 / 1 / 5$ & $1883-2010$ & $9.1(17)$ & $\cdots$ & $4.6(17)$ & $1.2 \cdot>0.2(16)$ \\
\hline $3 / 1 / 6$ & $1775-1857$ & $8.8(17)$ & $\ldots$ & $4.4(17)$ & $1.1->0.2(16)$ \\
\hline $4 / 1 / 4$ & $1898-2042$ & $9.1(17)$ & -- & $9.1(17)$ & $1.0->0.2(16)$ \\
\hline $4 / 1 / 5$ & $1767-1900$ & $8.6(17)$ & $\cdots$ & $8.7(17)$ & $0.6->0.1(16)$ \\
\hline $4 / 1 / 6$ & $1650-1788$ & $8.2(17)$ & - & $8.2(17)$ & $0.6 \cdot>0.1(16)$ \\
\hline
\end{tabular}

- Concentrations, read as $3.8 \times 10^{18}$ rear flame decaying to $0.7 \times 10^{18}$ at $4.0 \mathrm{~ms}$.

flame. Sodium concentrations are the order of $10^{11} \mathrm{~cm}^{-3}(\approx 0.1 \mathrm{ppm})$, the radicals are at least a few orders of magnitude greater, with total sulfur at the 1 to $2 \%$ level. Thus all 


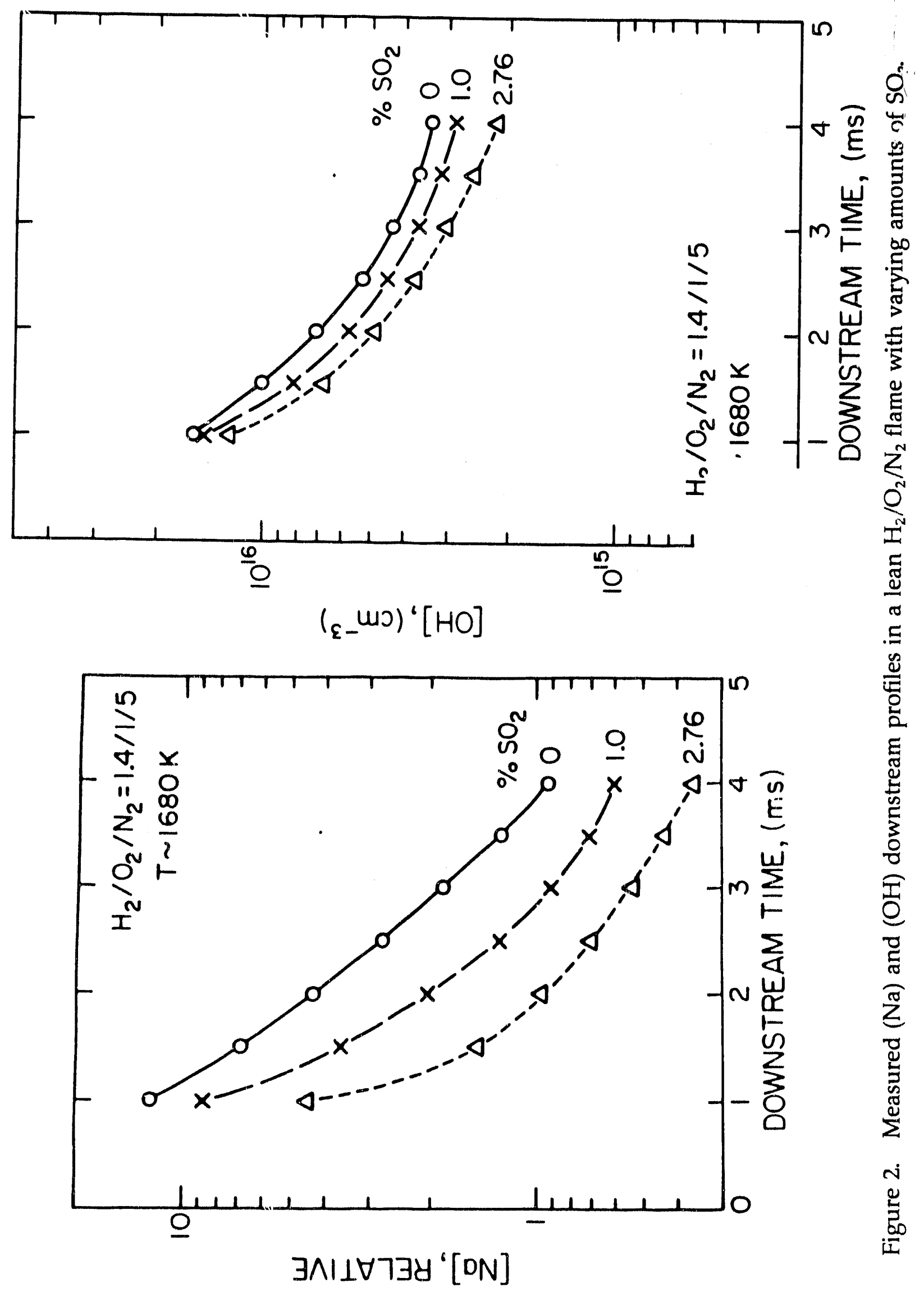


species can influence the concentrations of sodium species but sodium has nu effect on other atomic or molecular concentrations.

What is found at all stoichiometries is that the amour i of free sodium fractionally decreases in the presence of sulfur and reniains approximately constant at all downstreañ distances. This of itself is quite informative, implying that species whose flame profiles change quite markedly with time probably will not play significant roles. As will be seen, the decreases in $(\mathrm{Na})$ with added $\mathrm{SO}_{2}$ illustrated in Figure 2, result from two effects. The first, which is dominant in lean flames, is the increased sodium oxidation resulting from the sulfur catalyzed flame radical decay and in fact sodium/sulfur chemistry plays only a small role. On the other hand, sodium oxidation is minor in the rich flames, and sodium/sulfur compound formation makes a definite contribution.

\section{MODELING OVERVIEW}

The experimental data base consists of the non-equilibrium flame profiles of temperature, $\mathrm{OH}$ concentrations, and relative sodium concentrations, all with and without the addition of $\mathrm{H}_{2} \mathrm{~S}$ or $\mathrm{SO}_{2}$. From the temperature and $\mathrm{OH}$ measurements, along with the monitored sulfur addition to the flames, one can calculate the corresponding profiles of $\mathrm{H}_{2} \mathrm{O}$, the coupled radicals $\mathrm{H}$ and $\mathrm{O}$, the trace species $\mathrm{H}_{2}$ in lean flames and $\mathrm{O}_{2}$ in rich flames, and the concentrations of the sulfur species $\mathrm{S}, \mathrm{S}_{2}, \mathrm{SH}, \mathrm{H}_{2} \mathrm{~S}, \mathrm{SO}, \mathrm{SO}_{2}$ and $\mathrm{SO}_{3}$. These are plotted for a lean flame in Figure 3, and for a rich flame in Figure 4, with and without the addition of $1 \%$ sulfur.

In the lean flame series the radicals, $\mathrm{OH}, \mathrm{H}$ and $\mathrm{O}$, and the trace species, $\mathrm{H}_{2}$, exhibit larger nonequilibrium overshoots and subsequent rates of decay toward 


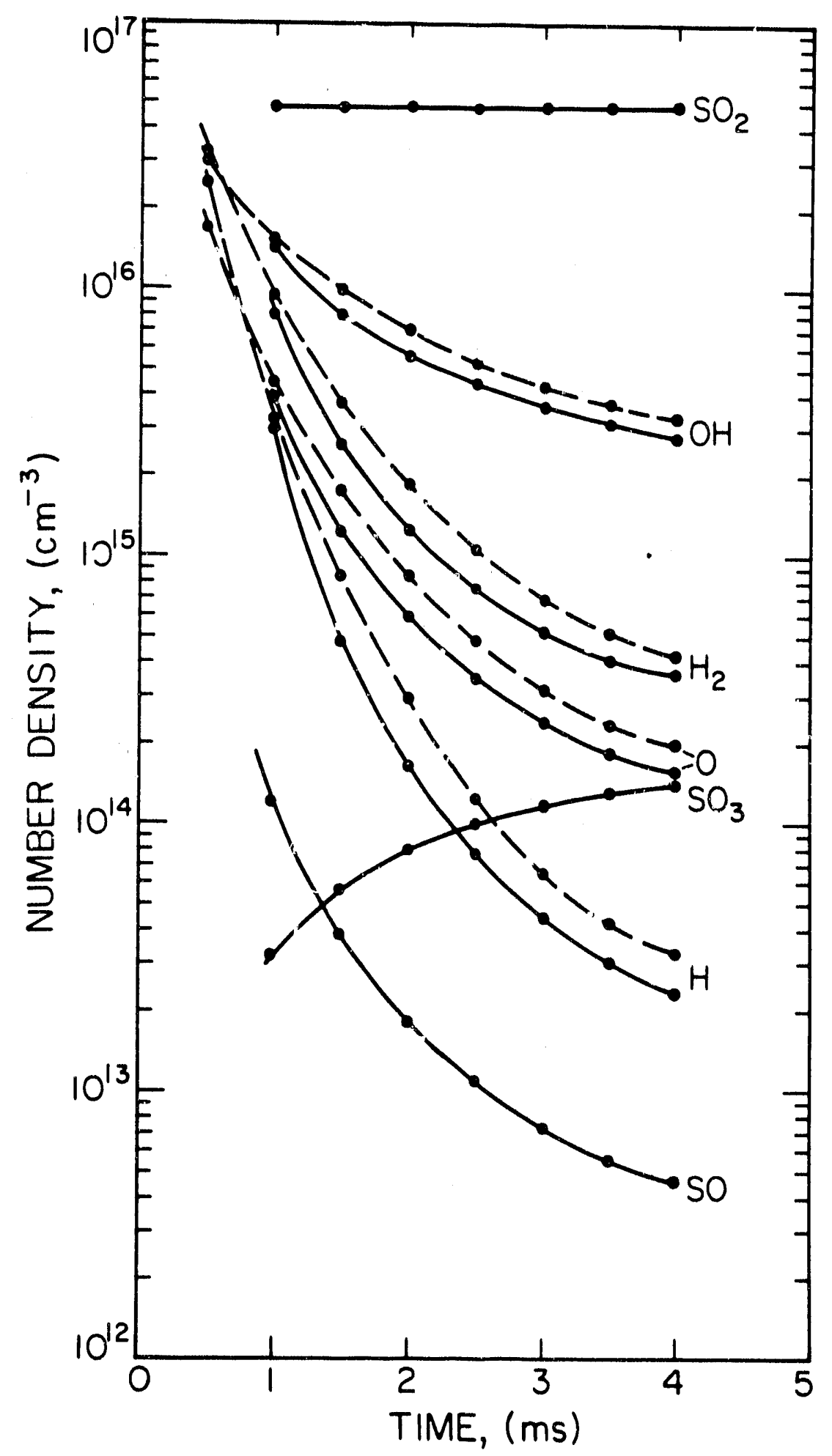

Figure 3. Trace species profiles in a lean $\mathrm{H}_{2} / \mathrm{O}_{2} / \mathrm{N}_{2}=1.4 / 1 / 5$ flame in the presence of $1 \% \mathrm{SO}_{2}$ (solid lines) or sulfur free (broken lines). 


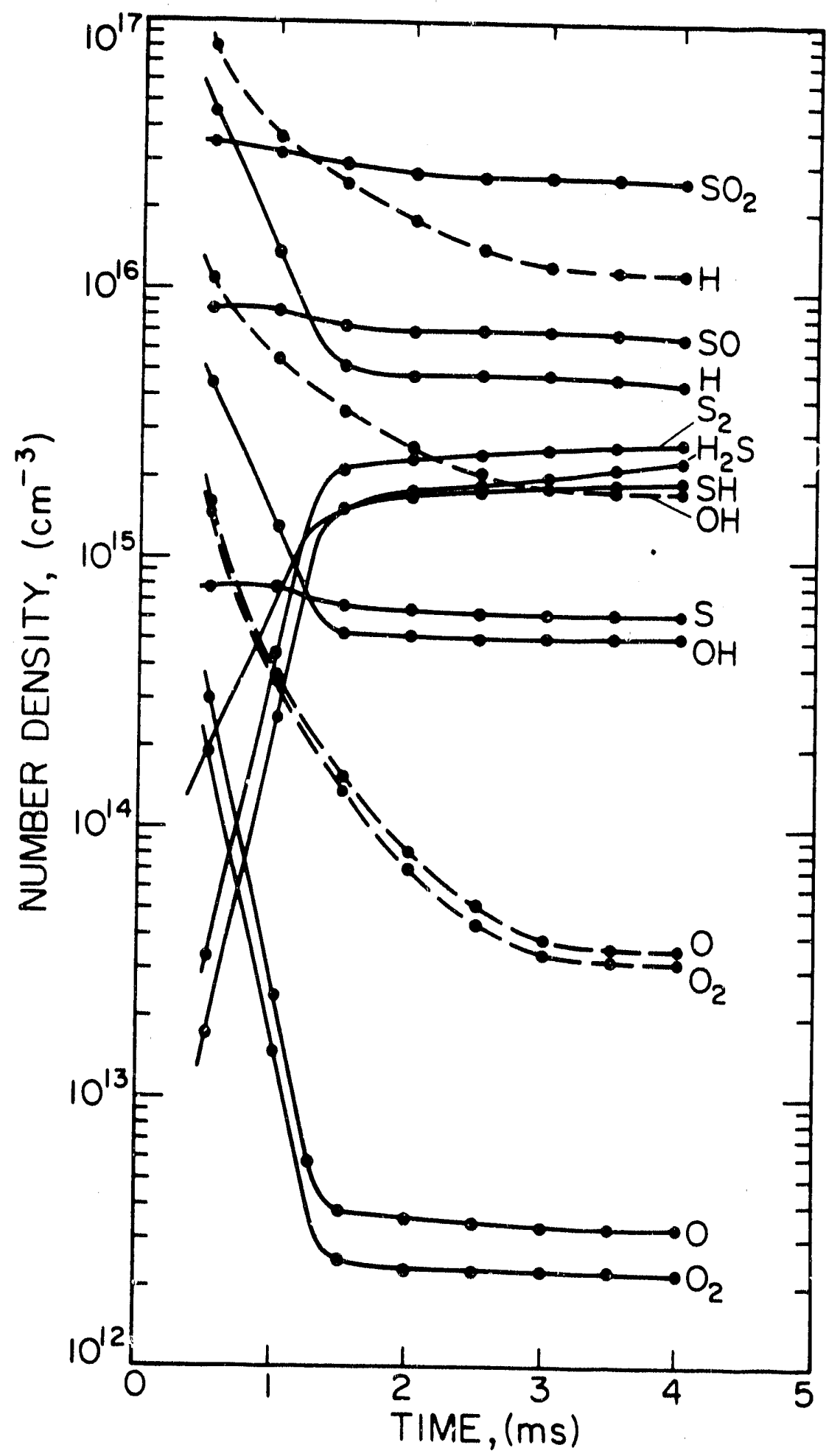

Figure 4. Trace species profiles in a rich $\mathrm{H}_{2} / \mathrm{O}_{2} / \mathrm{N}_{2}=3 / 1 / 6$ flame in the presence of $1 \%$ $\mathrm{H}_{2} \mathrm{~S}$ (solid lines) or sulfur free (broken lines) 
equilibrium as temperature is decreased. As noted in Figure 3, the only significant sulfur species in the lean flames is $\mathrm{SO}_{2} . \mathrm{SO}$ and $\mathrm{SO}_{3}$ concentrations are generally less than $1 \%$ those of the $\mathrm{SO}_{2}$ levels.

In the rich flames the radicals $\mathrm{OH}, \mathrm{H}$, and $\mathrm{O}$ and the trace species $\mathrm{O}_{2}$, exhibit a more enhaniced rate of decay with the addition of sulfur than is exhibited in the lean flames. Figures 3 and 4 can be compared in this regard. Decreasing temperature, as in the lean flames, exhibits increased radical decay amplitudes. The sulfur chemistry iri the rich flames is more complex than in the lean flames due to the presence of significant concentrations of numerous sulfur species. $\mathrm{SO}_{2}, \mathrm{SO}$, and $\mathrm{S}$ profiles are rather flat and not very sensitive to temperature. With increasing $\mathrm{H}_{2} / \mathrm{O}_{2}$ ratios the differences between their concentrations are decreased, but the relative ordering is maintained.

The reduced sulfur species $\mathrm{H}_{2} \mathrm{~S}, \mathrm{SH}$ and $\mathrm{S}_{2}$ exhibit similarly shaped profiles and have approximately equivalent concentrations in any given rich flame as seen in Figure 4. With increasing $\mathrm{H}_{2} / \mathrm{O}_{2}$ their concentrations increase but always are less than the SO levels. $\mathrm{SO}_{3}$ is negligible in rich flames. The broad data base, exhibiting $\mathrm{H}_{2} / \mathrm{O}_{2}$ ratios from $0.6 / 1$ to $4 / 1$ and temperatures from 1650 to $2400 \mathrm{~K}$, spans a wide range of differing conditions and proved to be invaluable for the identification and characterization of the dominant sodium/sulfur chemistry.

Initially, checks were made on the equilibrium of reactions (1-3) suggested by Fenimore $^{6}$ and Durie et al. ${ }^{7}$ Assuming that the enhanced sodium depletion with the addition of sulfur formed $\mathrm{NaSO}_{2}, \mathrm{NaS}$ or $\mathrm{NaSO}_{3}$ as indicated in reactions $(1,2$, or 3$)$, the corresponding equilibrium constants could be evaluated. However, the $\log K$ vs $1 / T$ graphs exhibited no trends approximating to the establishment of any such equilibria. 
A list of about 200 possible reactions can be written for the production and consumption of $\mathrm{NaS}, \mathrm{NaSH}, \mathrm{NaS}_{2}, \mathrm{NaOS}, \mathrm{NaSO}_{2}$, and $\mathrm{NaSO}_{3}$ which appear to be the most likely sodium/sulfur compounds to exist in rich or lean $\mathrm{H}_{2} / \mathrm{O}_{2} / \mathrm{N}_{2}$ flames. At the low sodium levels ( $<1 \mathrm{ppm})$ in this study, the formation of any disodium compounds, $\mathrm{Na}_{2} \mathrm{SO}_{4}$ for example, is kinetically suppressed and extremely improbable. Of the above sodium/sulfur species only $\mathrm{NaSH}$ exists at ordinary conditions ${ }^{29}$ and $\mathrm{NaSO}_{2}$ has been prepared in argon matrices..$^{30,31}$ None of these species have been directly identified in the gas phase. $\mathrm{NaS}, \mathrm{NaSH}, \mathrm{NaOS}$ and $\mathrm{NaS}_{2}$ are electronic analogs of $\mathrm{NaO}, \mathrm{NaOH}$, and $\mathrm{NaO}_{2}$, respectively, and may be expected to exist in flames. Before modeling of any type could be attempted, because of their ill-characterized nature, it was initially necessary to estimate their thermodynamic properties and assess the rate constants for this large reaction matrix involving these sodium/sulfur species.

\section{SODIUM/SULFUR SPECIES CHARACTERIZATION}

Molecular configurations, bond lengths, vibrational frequencies, and sodium-adduct bond strengths have been appraised to permit third law calculations of the thermochemical properties of each of the uncharacterized species. ${ }^{32}$ The broad reaction matrix consists predominantly of bimolecular reactions with a relatively small, but important set of termolecular processes. Estimates have been made for the gas kinetic collision frequencies of all the bimolecular processes. Forward and reverse rate constants have been related through calculated equilibrium constants. These assignments are such that when a forward or reverse reaction has a gas kinetic rate constant then the corresponding reverse or forward process does not exceed this. Three body rate constants 
for sodium with sulfur species were set initially equal to the rate constants for their sodium-oxygen analogs. ${ }^{10}$ The rate constants for the reverse dissociation processes were obtained through the c lculated equilibrium constants.

Some comments are in order concerning the errors these estimates may cause in any modeling effort. Equilibrium constants are required for each reaction in the model to relate the forward and reverse rate coefficients. Due to the form of the relationship, $\mathrm{K}_{\mathrm{eq}}=A \exp (-\Delta \mathrm{H} / \mathrm{RT})$, the equilibrium constants, and the rate constants they affect, are most sensitive to the bond strengths which control the enthalpy changes. At flame temperatures $(\approx 2000 \mathrm{~K})$, an uncertainty of about $12 \mathrm{~kJ} \mathrm{~mol}^{-1}$ in a bond strength will correspond to a factor of 2 uncertainty in the corresponding equilibrium constant. The coefficient A will involve, among other things, the moment of inertia and vibrational frequencies of one of these uncharacterized sodium/sulfur species. Very reasonable estimates may be made for the moment of inertia, $I$, and $K_{e q} \approx I^{1 / 2}$. For the vibrational frequency uncertainties, a $1 \%$ error in a frequency estimate will produce errors in the coefficient $\mathrm{A}$ of about $1 \%$ for a magnitude of $100 \mathrm{~cm}^{-1}, 0.7 \%$ for $1000 \mathrm{~cm}^{-1}$, and $0.3 \%$ for $3000 \mathrm{~cm}^{-1}$ at flame temperatures $(2000 \mathrm{~K})$. These are only moderate influences that will not seriously degrade rate constant estimates. Obviously, the greatest uncertainty will arise from bond strength estimates and this is where the greatest care has to be exercised.

Langhoff et al. ${ }^{33}$ have computed properties for a wide range of ionically bound molecules and show a rather good correlation between the energy, $D_{i o n}^{\circ}$ for dissociation to ions and bond length. In the upper half of Figure 5, experimentally based values of $\mathrm{D}_{\mathrm{ion}}^{\mathrm{o}}(\mathrm{MX})$ for lithium, sodium and poiassium oxides, dioxides, hydroxides, fluorides, chlorides, and bromides are plotted against their corresponding bond lengths. The semilog 


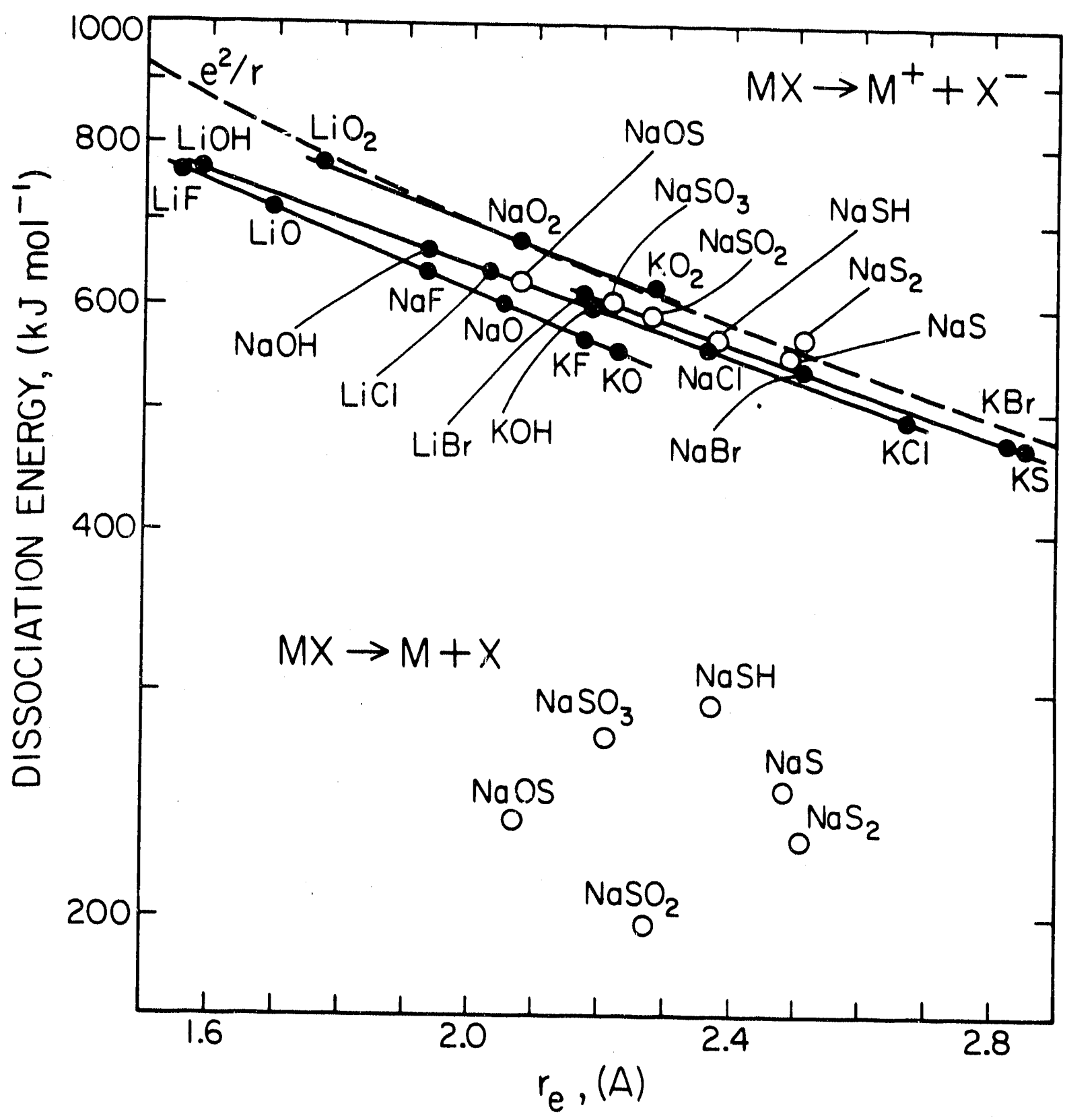

Figure 5. Correlation of internuclear separation and dissociation energies for alkali metal compounds, $\mathrm{MX}$, to their ions, $\mathrm{M}^{+}$and $\mathrm{X}$; or to $\mathrm{M}$ and $\mathrm{X}$ neutrals in the case of the six sodium/sulfur compounds. 
plots nicely correlate the different families of alkali compounds (solid lines through the solid points). This appears to be an effective estimation method and has been used for these sodium/sulfur compounds which are all expected to be highly ionic. For the processes

$$
\begin{aligned}
M X & \rightarrow M+X \\
& \rightarrow M^{+}+X^{-}
\end{aligned}
$$

the corresponding heats of reaction are given by

$$
D_{0}^{\circ}=\Delta_{\mathrm{f}} \mathrm{H}_{0}^{\circ}(\mathrm{M})+\Delta_{\mathrm{f}} \mathrm{H}_{0}^{\circ}(\mathrm{X})-\Delta_{\mathrm{f}} \mathrm{H}_{0}^{\mathrm{o}}(\mathrm{MX})
$$

and

$$
D_{\text {ion }}=\Delta_{\mathrm{f}} \mathrm{H}_{0}^{\circ}\left(\mathrm{M}^{+}\right)+\Delta_{\mathrm{f}} \mathrm{H}_{0}^{\circ}(\mathrm{X})-\Delta_{\mathrm{f}} \mathrm{H}_{0}^{\mathrm{o}}(\mathrm{MX}) \text {. }
$$

These can be reduced to the relationship

$$
D_{\text {ion }}^{\circ}(M X)-D_{0}^{\circ}(M X)=I P-E A
$$

which shows the difference between $D_{\text {ion }}^{\circ}(M X)$ and $D_{0}^{\circ}(M X)$ to be accurately known if the ionization potential (IP) for $M$, and the electron affinity (EA) for $X$ are well established. $\underline{\mathrm{NaS}}$

No experimental data are available for NaS. However, Langhoff et $\mathrm{al}^{33}$ and Partridge et al. ${ }^{34}$ have made ab initio calculations for the spectroscopic properties of the diatomic alkali sulfides and oxides. Their oxide estimates are in reasonable accord with available measured values. For $\mathrm{NaS}$ they determined $\mathrm{r}_{\mathrm{e}}=0.2487 \mathrm{~nm}, \omega_{\mathrm{e}}=339 \mathrm{~cm}^{-1}$, and $\mathrm{D}_{0}^{\circ}=256 \mathrm{~kJ} \mathrm{~mol}^{-1}$. For KS their $\mathrm{D}_{0}^{\circ}$ calculation yielded $259 \mathrm{~kJ} \mathrm{~mol}^{-1}$. Farber et al. ${ }^{35}$ in a mass spectrometric measurement, derived $\mathrm{D}_{0}(\mathrm{KS})=251 \mathrm{~kJ} \mathrm{~mol}^{-1}$. Consequently, for the present analysis the calculated value for $\mathrm{D}_{0}^{\circ}(\mathrm{NaS})^{34}$ was scaled and a value of $249 \mathrm{~kJ} \mathrm{~mol}^{-1}$ taken. The reasonableness of this magnitude is reinforced by the correlations of Figure 5 . This 
shows the value for KS of Farber et al..$^{3}$ and that taken for NaS. It cannot be seriously in error. As expected, it is also slightly weaker than $\mathrm{NaO}$. This and the other molecular parameters for $\mathrm{NaS}$ are summarized in Table 2.

$\underline{\mathrm{NaSH}}$

No measurements are available for the molecular properties of alkali hydrosulfides. In an ab initio study, Pappas $^{36}$ found the alkali hydrosulfides to have nonlinear structures in contrast to their linear alkali hydroxide analogs. In addition he calculated a dissociation energy to $\mathrm{Na}^{+}$and $\mathrm{SH}^{-}$of about $615 \mathrm{~kJ} \mathrm{~mol}^{-1}$ which is about $59 \mathrm{~kJ} \mathrm{~mol}^{-1}$ in excess of the binding energy, $e^{2 / r_{e}}$. The corresponding value for $D_{0}^{\circ}(\mathrm{Na}-\mathrm{SH})$ would be $343 \mathrm{~kJ} \mathrm{~mol}^{-1}$, a very stable compound, even more so than $\mathrm{NaOH}$, which clearly is unacceptable. As a result, we have estimated the properties from those of its electronic analog, $\mathrm{NaOH}$. For the ionically bound $\mathrm{NaSH}$ we can set $r_{e}(\mathrm{NaS}-\mathrm{H})=r_{e}(\mathrm{~S}-\mathrm{H}-)$ which was found to have a value of $0.1351 \mathrm{~nm}$ in a velocity modulation laser spectroscopy measurement. ${ }^{37}$ From the approximation

$$
r_{e}(\mathrm{NaO})-r_{e}(\mathrm{Na}-\mathrm{OH})=r_{e}(\mathrm{Na}-\mathrm{S})-r_{e}(\mathrm{Na}-\mathrm{SH})
$$

with $r_{e}(\mathrm{NaO})=0.205,{ }^{38} \mathrm{r}_{\mathrm{e}}(\mathrm{Na}-\mathrm{OH})=0.193,{ }^{39}$ and $\mathrm{r}_{\mathrm{e}}(\mathrm{Na}-\mathrm{S})=0.249 \mathrm{~nm}^{34}$ we estimate $\mathrm{r}_{\mathrm{e}}(\mathrm{Na}$ $\mathrm{SH})=0.237 \mathrm{~nm}$ and assume a linear structure. The vibrational frequencies can be estimated with the valence force approach to linear $\mathrm{XYZ}$ molecules treated in some detail by Herzberg. ${ }^{40}$ The relationships for the vibrational frequencies are

$$
\begin{gathered}
4 \pi^{2} c^{2}\left(\omega_{1}^{2}+\omega_{3}^{2}\right)=k_{1}\left(1 / m_{x}+1 / m_{y}\right)+k_{2}\left(1 / m_{y}+1 / m_{z}\right), \\
16 \pi^{4} c^{4} \omega_{1}^{2} \omega_{3}^{2}=k_{1} k_{2}\left(m_{x}+m_{y}+m_{z}\right) /\left(m_{x} m_{y} m_{z}\right), \\
4 \pi^{2} c^{2} \omega_{2}^{2}=\left[1 /\left(r_{1} r_{2}\right)\right]^{2}\left[r_{1}^{2} / m_{z}+r_{2}^{2} / m_{x}+\left(r_{1}+r_{2}\right) / m_{y}\right] k_{\delta}
\end{gathered}
$$

where $\omega_{1}$ and $\omega_{3}$ are the stretch and $\omega_{2}$ the bending frequencies; $\mathrm{m}_{\mathrm{x}}, \mathrm{m}_{\mathrm{y}}$ and $\mathrm{m}_{\mathrm{z}}$ the atom 


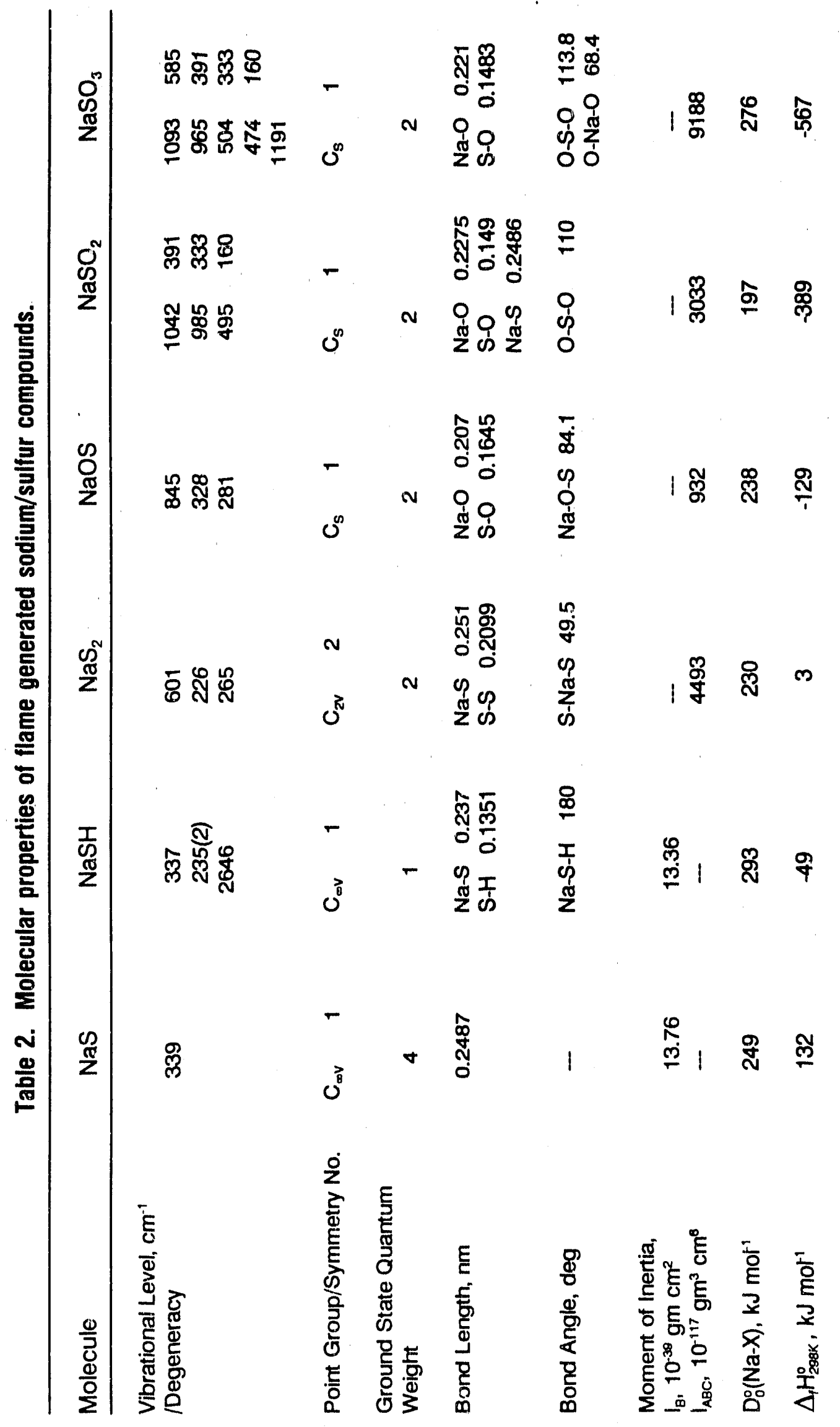


masses for $\mathrm{NaSH}=X Y Z ; r_{1}$ and $r_{2}$ the bond lengths for $X-Y Z$ and $X Y-Z ; k_{1}$ and $k_{2}$ the force constants for the $X-Y$ and $Y-Z$ stretch modes, respectively and $k_{s}$ the bending constant. The first two equations can be solved for the stretch frequencies, $\omega_{1}$ and $\omega_{2}$ assuming that the force constants $\mathrm{k}_{1}$ and $\mathrm{k}_{2}$ for $\mathrm{NaSH}$ are equal to those for the diatoms $\mathrm{NaS}$ and $\mathrm{SH}$, respectively. With $\omega_{\mathrm{e}}(\mathrm{NaS})=339$ and $\omega\left(\mathrm{SH}^{-}\right)=2645.6 \mathrm{~cm}^{-137}$ we so obtain $\omega_{1}=337$ and $\omega_{3}=2646 \mathrm{~cm}^{-1}$ for NaSH. The large difference between $\omega_{1}$ and $\omega_{3}$ cause them to be uncoupled and reflect the frequencies of the corresponding diatoms.

Making reasonable estimates for the bending constant $k_{\delta}$ and the bending frequency is a little more difficult. The valence force treatment was applied to the alkali hydroxides, lithium through cesium, for which reasonable data are available..$^{39}$ Their bending constants were calculated from the corresponding bending frequencies using the above equation. These were found to vary only $\pm 10 \%$ about a mean value of $0.053 \times 10^{-11}$ dyne $\mathrm{cm} \mathrm{rad}-1$. Assuming that $\mathrm{k}_{\delta}$ values for $\mathrm{NaSH}$ and $\mathrm{NaOH}$ are similar, this predicts $\omega_{2}(\mathrm{NaSH})=235 \mathrm{~cm}^{-1}$.

$\mathrm{NaSH}$ is isoelectronic with $\mathrm{NaCl}$ and the two do have essentially equal bond lengths, $0.237 \mathrm{~nm}$ as against that for $\mathrm{NaCl}$ of $0.2361 \mathrm{~nm} .{ }^{39}$ Comparisons in Figure 5 of other isoelectronic pairs such as the alkali fluorides and hydroxides shows that each has the same metal-adduct bond length, but the corresponding hydroxide exhibits a somewhat larger value of $\mathrm{D}_{\text {ion. }}^{\circ}$. For example, with $\mathrm{NaOH}, \mathrm{D}_{\text {ion }}^{o}=660$ against $641 \mathrm{~kJ} \mathrm{~mol}^{-1}$ for $\mathrm{NaF}$. Treating the $\mathrm{NaSH} / \mathrm{NaCl}$ pair in analogous manner, taking $\mathrm{D}_{\text {ion }}^{\circ}(\mathrm{NaCl})=554 \mathrm{~kJ}$ $\mathrm{mol}^{-1}$, this predicts a value of about $565 \mathrm{~kJ} \mathrm{~mol}^{-1}$ for $\mathrm{D}_{\text {ion }}(\mathrm{Na}-\mathrm{SH})$. The corresponding value for $\mathrm{D}_{0}^{\circ}(\mathrm{NaSH})$ is then $293 \mathrm{~kJ} \mathrm{~mol}^{-1}$, the most stable of the sodium/sulfur molecules and 
slightly weaker than $\mathrm{NaOH}$. These estimated values for the various properties of $\mathrm{NaSH}$ are summarized in Table 2.

$\underline{\mathrm{NaS}}_{2}$

No structural data are available for the $\mathrm{NaS}_{2}$ molecule. A triangular shape has been assumed as an electronic analog for the ionically bound $\mathrm{NaO}_{2}$, of known triangular $\mathrm{C}_{2 \mathrm{v}}$ symmetry. ${ }^{11-43}$ The bond length, $0.2099 \mathrm{~nm}$ and the vibrational frequency, $601 \mathrm{~cm}^{-1}$, for $\mathrm{S}_{2}^{-}-4$ vare assumed to be unchanged in $\mathrm{NaS}_{2}$. It is known that the $\mathrm{O}_{2}^{-}$frequency in $\mathrm{NaO}_{2}{ }^{41} 1080 \mathrm{~cm}^{-1}$, is essentially equal to that of the $\mathrm{O}_{2}^{-}$diatom, ${ }^{4} 1090 \mathrm{~cm}^{-1}$. The Na-S bond length, $0.251 \mathrm{~nm}$, was scaled from the NaS diatomic bond length using the same proportional increase for the $\mathrm{Na}-\mathrm{O}$ bond distance in going from $\mathrm{NaO}$ with $0.205 \mathrm{~nm}^{44}$ to $\mathrm{NaO}_{2}$ with $0.207 \mathrm{~nm}^{30}$ The Na-S stretch frequencies were scaled from that for $\mathrm{NaS}$ by the same ratios as noted for $\mathrm{NaO}\left(50 \mathrm{~cm} \mathrm{~cm}^{-1}\right)^{38}$ and $\mathrm{NaO}_{2}\left(333\right.$ and $\left.391 \mathrm{~cm}^{-1}\right) .^{41-33}$ The dissociation of $\mathrm{NaS}_{2}$ to ions was assumed to be correlated with the $\mathrm{D}_{\text {ion }}^{\circ}$ values for the alkali dioxides in Figure 5 indicating $565 \mathrm{~kJ} \mathrm{~mol}^{-1}$. This yields a value for $\mathrm{D}_{0}^{\circ}\left(\mathrm{Na}-\mathrm{S}_{2}\right)=230 \mathrm{~kJ} \mathrm{~mol}^{-1}$. These estimates for the $\mathrm{NaS}_{2}$ structural, spectral and thermochemical parameters are listed in Table 2.

$\underline{\mathrm{NaOS}}$

During the course of this study no docuniented struciural information was available for $\mathrm{NaOS}$. Our modeling was based on a triangular shape as an electronic analog of $\mathrm{NaO}_{2}{ }^{41+3}$ The molesule can be assumed to be primarily ionic and the bond length $\mathrm{r}_{\mathrm{e}}(\mathrm{Na}-\mathrm{O})$ was taken equal to that in $\mathrm{NaO}_{2}$ about $0.207 \mathrm{~nm}$, with $\mathrm{r}_{\mathrm{e}}(\mathrm{Na}-\mathrm{S})$ equal to that in $\mathrm{NaS}_{2}$, or $0.251 \mathrm{~nm}$. The $\mathrm{SO}^{-}$bond length was assumed equal to that of diatomic SO or $0.164 .5 \mathrm{~nm}^{4}$ 
The vibrational frequency of $\mathrm{SO}^{-}$in $\mathrm{NaOS}$ was assumed to be the same as that for diatomic SO. Although no experimental data exist for this, it was noted that the known value of $\omega(\mathrm{SO})=1149 \mathrm{~cm}^{-1}$ is the average of $\omega\left(\mathrm{O}_{2}\right)=1580$ and $\omega\left(\mathrm{S}_{2}\right)=726 \mathrm{~cm}^{-1} \cdot{ }^{4}$ Consequently, a value of $\omega\left(\mathrm{SO}^{-}\right)=845 \mathrm{~cm}^{-1}$ can be obtained by similarly averaging $\omega\left(\mathrm{O}_{2}{ }^{-}\right)=1090$ and $\omega\left(\mathrm{S}_{2}{ }^{-}\right)=601 \mathrm{~cm}^{-1}$. Correspondingly, the remaining frequencies involving the $\mathrm{Na}-\mathrm{S}$ and $\mathrm{Na}-\mathrm{O}$ interactions in $\mathrm{NaOS}$ were taken as averages of the same modes in $\mathrm{NaO}_{2}$ and $\mathrm{NaS}_{2}$.

The bond strength for $\mathrm{NaOS}$ dissociation to $\mathrm{Na}+\mathrm{SO}$ undoubtedly is bound by the flame measured value, ${ }^{10} \mathrm{D}_{0}^{\mathrm{o}}\left(\mathrm{Na}-\mathrm{O}_{2}\right)=243$, and $\mathrm{D}_{0}^{\circ}\left(\mathrm{Na}-\mathrm{S}_{2}\right)=230 \mathrm{~kJ} \mathrm{~mol}^{-1}$ estimated in Table 2. Assuming $D_{0}^{\circ}(\mathrm{Na}-\mathrm{OS})=238 \mathrm{~kJ} \mathrm{~mol}^{-1}$ yields $D_{\text {ion }}(\mathrm{Na}-\mathrm{OS})=628 \mathrm{~kJ} \mathrm{~mol}^{-1}$. These parameters are plotted in Figure 5 and appear to be reasonable.

Near the completion of this effort we speculated that a linear $\mathrm{NaOS}$ might be significantly more stable and brought the problem to the attention of H.F. Schaefer III at the University of Georgia. As a result, Jin and Schaefer ${ }^{\text {s5 }}$ carried out ab initio calculations for $\mathrm{NaOS}$. They established that a bent $\mathrm{NaOS}\left({ }^{2} \mathrm{~A}^{\prime \prime}\right)$ best represents the ground state with a value for $\mathrm{D}_{0}^{\circ}(\mathrm{Na}-\mathrm{OS}) \approx 209 \mathrm{~kJ} \mathrm{~mol}^{-1}$ without correction for zero point vibrational energy. Their corresponding bond lengths are $r_{e}(\mathrm{Na}-\mathrm{OS})=0.2123$ and $r_{e}(\mathrm{NaO}-\mathrm{S})=0.1577 \mathrm{~nm}$ with a bond angle of $87.8^{\circ}$. A linear $\mathrm{NaOS}\left({ }^{2} \Pi\right)$ lies about $33 \mathrm{~kJ} \mathrm{~mol}^{-1}$ above the bent ground state. The alternate linear $\mathrm{NaSO}$ structure lies at a much higher energy and plays no role. As a result, the correct chemical formulation should always be written as $\mathrm{NaOS}$. If out of habit or custom this appears anywhere as $\mathrm{NaSO}$ this structural aspect should be remembered. Their molecular configuration yields a prexponential term in the equilibrium constant for $\mathrm{NaOS}$ formation that differs from the estimate used in the present study by only $12 \%$. However, considering the bond strengths for $\mathrm{NaO}_{2}$ and $\mathrm{NaS}_{2}$ discussed already 
and the correlations in Figure 5, it would appear that their calculated bond strength is too small.

$\underline{\mathrm{NaSO}}_{2}$

The $\mathrm{NaSO}_{2}$ structure that has been used was based on an electron spin resonance study ${ }^{30}$ in an argon matrix. This yielded a non-planar configuration with the sodium equidistant from the two O-atoms. Bond distances are $r_{e}(\mathrm{Na}-\mathrm{O})=0.228$ and $r_{e}(\mathrm{NaS})=0.245$ $\mathrm{nm}$. The bond length, $\mathrm{r}_{\mathrm{e}}(\mathrm{O}-\mathrm{S})$, in $\mathrm{SO}_{2}^{-}$was taken as $0.149 \mathrm{~nm}$ with a $110^{\circ} \mathrm{O}-\mathrm{S}-\mathrm{O}$ bond angle, and the vibrational frequencies, 985,495 and $1042 \mathrm{~cm}^{-1}$ are those determined by Milligan and Jacox in an infrared study of $\mathrm{Na}$ and $\mathrm{SO}_{2}$ deposited in an argon matrix. ${ }^{46}$ The stretch frequencies 391 and $333 \mathrm{~cm}^{-1}$, determined by Andrews ${ }^{41}$ for $\mathrm{NaO}_{2}$ in an argon matrix were assurned for the sodium oxygen interaction in $\mathrm{NaSO}_{2}$ together with $160 \mathrm{~cm}^{-1}$ from a $\mathrm{Na}_{2} \mathrm{SO}_{4}$ analysis. ${ }^{39}$ These parameters are listed in Table 2 . They have been used rather than the alternate values of Bencivenni et al., ${ }^{31}$ who also have analyzed infrared and Raman spectra of $\mathrm{NaSO}_{2}$ isolated in an argon matrix. However, they favor a planar configuration which they have further justified in more recent ab initio calculations. ${ }^{47} \mathrm{An}$ additional study is needed to resolve this controversy. Its consequences are that it introduces an uncertainty in the equilibrium constant value, the major contribution arising from this symmetry factor. A linear structure would indicate a two-fold larger magnitude.

$\underline{\mathrm{NaSO}}_{3}$

Estimates for the molecular properties of $\mathrm{NaSO}_{3}$ are based on the FTIR studies of $\mathrm{SO}_{3} \cdot$ in a mixture of $\mathrm{Cs}$ and $\mathrm{SO}_{3}$ in an argon matrix, and an ab initio analysis of $\mathrm{SO}_{3}{ }^{-}$by Stanbury et al. ${ }^{48}$ They computed $\mathrm{r}_{\mathrm{e}}(\mathrm{S}-\mathrm{O})=0.1483 \mathrm{~nm}$ with O-S-O angles of $113.8^{\circ}$ for a 
non-planar $\mathrm{SO}_{3}$. They found the alkali ion coupled to two of the three oxygen atoms. We have assumed the $\mathrm{Na}$ and $\mathrm{SO}_{2}$ components to be coplanar. The $\mathrm{Na}-\mathrm{O}$ distance is taken to be equal to that in $\mathrm{Na}_{2} \mathrm{SO}_{4}{ }^{39}$ Stanbury et al. ${ }^{48}$ identified frequencies for $\mathrm{SO}_{3}$. Those assigned to the $\mathrm{Na}-\mathrm{O}$ interaction correspond to the values estimated for $\mathrm{NaSO}_{2}$.

We estimate the $\mathrm{Na}^{+}-\mathrm{SO}_{3}^{-}$bond strength to be about $607 \mathrm{~kJ} \mathrm{~mol}^{-1}$ from the correlations noted in Figure 5. This corresponds to $\mathrm{D}_{0}\left(\mathrm{Na}-\mathrm{SO}_{3}\right)=276 \mathrm{~kJ} \mathrm{~mol}^{-1}$. These parameters are summarized in Table 2, and $D_{0}^{\circ}$ and $D_{\text {ion }}^{\circ}$ values are plotted in Figure 5.

\section{KINETIC MODELING}

As indicated, the introduction of sulfur to the sodium/flame media introduces the possibility of many chemical reactions between the numerous possible species. A typical reaction scheme for $\mathrm{NaOS}$ formation and consumption is seen in Figure 6. The reaction net is an expansion of the sodium oxidation model for which 17 possible reactions interconnect $\mathrm{Na}, \mathrm{NaO}_{2}, \mathrm{NaOH}$ and $\mathrm{NaO},{ }^{9,10}$ Four boxes for $\mathrm{NaSH}, \mathrm{NaSO}_{2}, \mathrm{NaS}$, and $\mathrm{NaS}_{2}$ are also shown. However, the corresponding complicated reaction nets connecting these latter species are not illustrated nor are those reactions that connect one sulfur species to another, otherwise the figure would be far too confusing.

All the flame data refer to a time frame of 0.25 to $4 \mathrm{~ms}$ in the burnt gases measured from the primary reaction zone. In this region, concentrations and temperatures are not changing rapidly and the kineuic fluxes are such that a steady state distribution has been illustrated in the sodium oxidation cycle.,10 The sodium distribution effectively adjusting and tracking the demise of the flame radicals. The kinetic fluxes controlling the major channels that involve the various sodium/sulfur compounds also appear to be sufficiently 


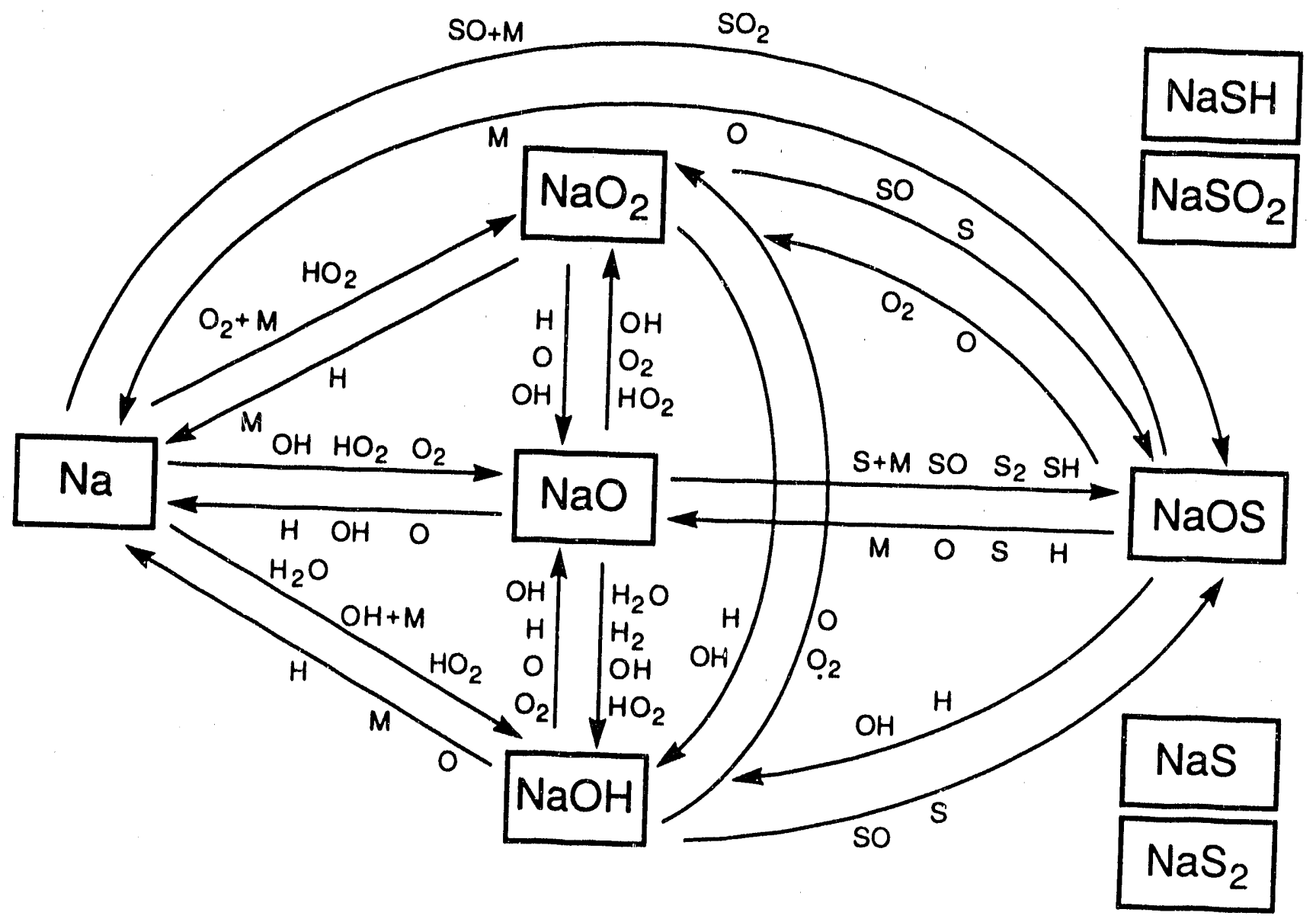

Figure 6. Sodium/sulfur reaction scheme. The reactions connecting $\mathrm{NaSH}, \mathrm{NaSO}_{2}$ complication. 
large that there is no reason to doubt that these also will become locked into a corresponding steady state distribution. Consequently, equipped with the initial estimates for the rate constants of the many possible reactions, this permitted a preliminary steady state kinetic analysis to be examined on this large block of reactions.

With no sulfur present, the total sodium concentration is given by the equation

$$
(\mathrm{Na})_{\mathrm{T}}=(\mathrm{Na})_{0}+\left(\mathrm{NaO}_{2}\right)_{0}+(\mathrm{NaOH})_{0}+(\mathrm{NaO})_{0}
$$

and with sulfur by

$$
\begin{aligned}
(\mathrm{Na})_{T}= & (\mathrm{Na})_{6}+\left(\mathrm{NaO}_{2}\right)_{8}+(\mathrm{NaOH})_{6}+(\mathrm{NaO})_{6}+(\mathrm{NaOS})+ \\
& \left(\mathrm{NaSO}_{2}\right)+\left(\mathrm{NaSO}_{3}\right)+(\mathrm{NaSH})+(\mathrm{NaS})+\left(\mathrm{NaS}_{2}\right) .
\end{aligned}
$$

The subscript " $\mathrm{s}$ " indicates the presence of sulfur. Eliminating $(\mathrm{Na})_{T}$ we obtain

$$
(\mathrm{Na})_{s}=(\mathrm{INa})_{0}(1+\mathrm{x}+\mathrm{y}+\mathrm{z})_{0} /(1+\mathrm{x}+\mathrm{y}+\mathrm{z}+\mathrm{p}+\mathrm{q}+\mathrm{r}+\mathrm{u}+\mathrm{v}+\mathrm{w})_{\mathrm{s}}
$$

where $x=\left(\mathrm{NaO}_{2}\right) /(\mathrm{Na}), y=(\mathrm{NaOH}) /(\mathrm{Na}), z=(\mathrm{NaO}) /(\mathrm{Na}), \mathrm{p}=(\mathrm{NaOS}) /(\mathrm{Na}), \mathrm{q}=\left(\mathrm{NaSO}_{2}\right) /(\mathrm{Na})$, $\mathrm{r}=\left(\mathrm{NaSO}_{3}\right) /(\mathrm{Na}), \mathrm{u}=(\mathrm{NaSH}) /(\mathrm{Na}), \mathrm{v}=(\mathrm{NaS}) /(\mathrm{Na})$, and $\mathrm{w}=\left(\mathrm{NaS}_{2}\right) /(\mathrm{Na})$. The equation relates the sodium concentrations with and without sulfur at corresponding times in the profiles for a given $\mathrm{H}_{2} / \mathrm{O}_{2} / \mathrm{N}_{2}$ flame. The values $x, y, z, p, q, r, u, v, w$ were evaluated in a matrix solution of the set of steady state kinetic relaijons applied to the production and consumption of the trace species $\mathrm{Na}, \mathrm{NaO}_{2}, \mathrm{NaOH}, \mathrm{NaO}, \mathrm{NaOS}, \mathrm{NaSO}_{2} \mathrm{NaSO}_{3}, \mathrm{NaSH}$, $\mathrm{NaS}$, and $\mathrm{NaS}_{2}$ all with concentrations less than $0.1 \mathrm{ppm}$.

The parameter $(1+x+y+z)_{0}$ is calculated using the oxidation model applied to the sulfur free flames.,10 The parameter $(1+x+y+z+p+q+r+u+v+w)_{s}$ is evaluated for the sulfur bear ing flames and is modeled to optimize agreement between the calculated $(\mathrm{Na})_{\text {s }}$ values and those observed experimentally.

Attenuating multipliers were applied to the rate constants for the bimolecular 
reactions, initially set at their gas kinetic values, to achieve optimal agreement between calculated and experimental values for $(\mathrm{Na})$. Where possible, the attenuation factors for many of the sodium/sulfur reaction rates were set equal to the corresponding factors for chemical analog sodium/oxygen reactions determined in the less complex oxidation study. 9,10

The large list of possible reactions was screened to identify the controlling chemistry connecting $\mathrm{NaSO}_{3}, \mathrm{NaSO}_{2}, \mathrm{NaOS}, \mathrm{NaSH}, \mathrm{NaS}$, and $\mathrm{NaS}_{2}$ with the sodium oxidation species, $\mathrm{Na}, \mathrm{NaO}_{2}, \mathrm{NaOH}$, and $\mathrm{NaO}$, and with each other. Fortunately, it was immediately noted that many of the candidate reactions had minor kinetic fluxes resulting from large thermal barriers and/or small reactant concentrations. Also, early in this exercise, it was found that $\mathrm{NaSO}_{3}$ could not be a kinetically viable sodium/sulfur product because of the low concentrations of $\mathrm{SO}_{3}$ in these flames. In the sodium flame oxidation chemistry it had previously been found that nnly five out of the possible seventeen reactions were pivotal in controlling the kinetic fluxes. Similarly, in the case of added sulfur it was discovered that only sixteen reactions can become dominant in connecting the sodium sulfidation products with the sodium oxidation species. In addition, ten reactions can play a role interconnecting $\mathrm{NaSO}_{2} \mathrm{NaOS}, \mathrm{NaSH}, \mathrm{NaS}$, and $\mathrm{NaS}_{2}$ with each other. However, these were found to be of secondary importance and it was not possible to accurately assign their relative contribution to the total sodium/sulfur chemistry.

The set of rate constants that was found to adequately model these systems is indicated in Table 3. Significant degrees of sensitivity to absolute rate constant values was indicated only in those reactions marked by an asterisk. In the case of the various sodium/sulfur compounds hese involve the efficient termolecular production reactions 
Table 3. Rate constants utilized in modeling sodium/sulfur flame chemistry, $\mathrm{cm}$ molecule $\mathrm{s}$ units.

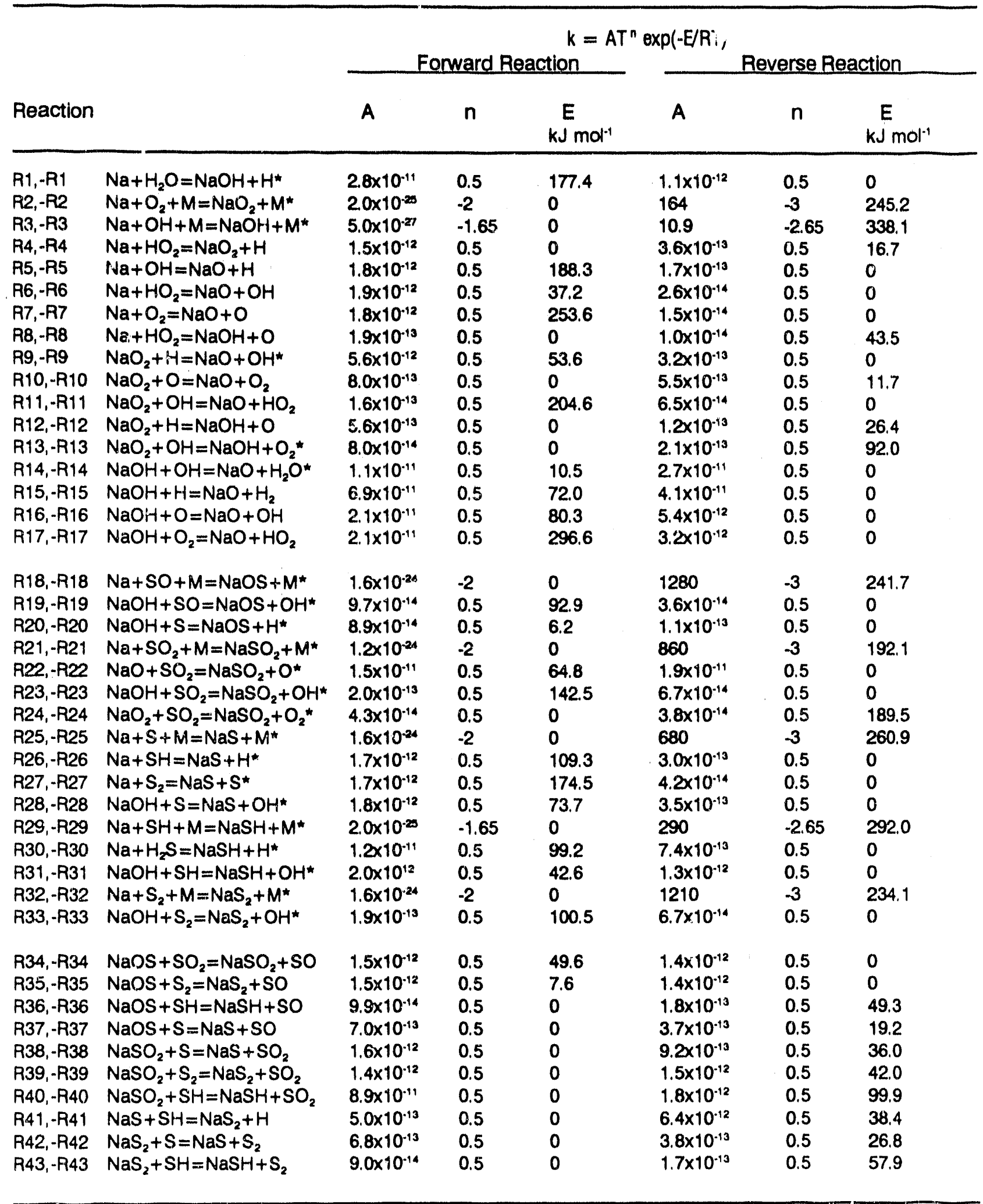


coupled to the major channels which together with thermal dissociation destroy the compound, coupling it back to the sodium oxidation loop. Often there is little sensitivity in the kinetic model to effectively distinguish between some of these radical induced destruction channels and fits may take on global kinetic aspects. A certain kinetic flux is required by the model and one of several reactions can be equally satisfactory. As a result, although asterisked, the rate constants in Table 3 for some of the bimolecular reactions involved in the radical induced destruction of the sodium/sulfur compounds remain only qualitative in nature in that they may not be uniquely identified.

On examining the flame data, $\mathrm{NaSO}_{2}$ appears to be the only significant sodium/sulfur product in the lean flames. All other sodium/sulfur products exhibited negligible contributions to the lean flame chemistry. This result is not too surprising considering the dominance of $\mathrm{SO}_{2}$ in lean flames clearly indicated in Figure 3. It is the concentration effect that makes it essentially impossible for any of the other sodium/sulfur molecules to be formed. However, what is unexpected is the small steady state concentration of $\mathrm{NaSO}_{2}$. A comparison of the experimental and calculated values for $(\mathrm{Na})_{\mathrm{s}}$ in a lean $\mathrm{H}_{2} / \mathrm{O}_{2} / \mathrm{N}_{2}$ flame, is plotted in Figure 7. Although there is a significant enhanced depletion of sodium indicated upon adding sulfur, this is seen to result mainjy from adjustments in the sodium oxidation distribution due to the reduced flame radical concentrations. The actual amount of $\mathrm{NaSO}_{2}$ formed is rather small in terms of the total sodium content. Nevertheless, the kinetic fluxes producing and destroying $\mathrm{NaSO}_{2}$ are very significant even though only a small steady state distribution is produced. The $\mathrm{NaSO}_{2}$ either thermally dissociates, or is converted to $\mathrm{NaO}_{2}$ or $\mathrm{NaOH}$ and does perturb very slightly the sodium oxidation distribution because of the large fluxes involved. The 


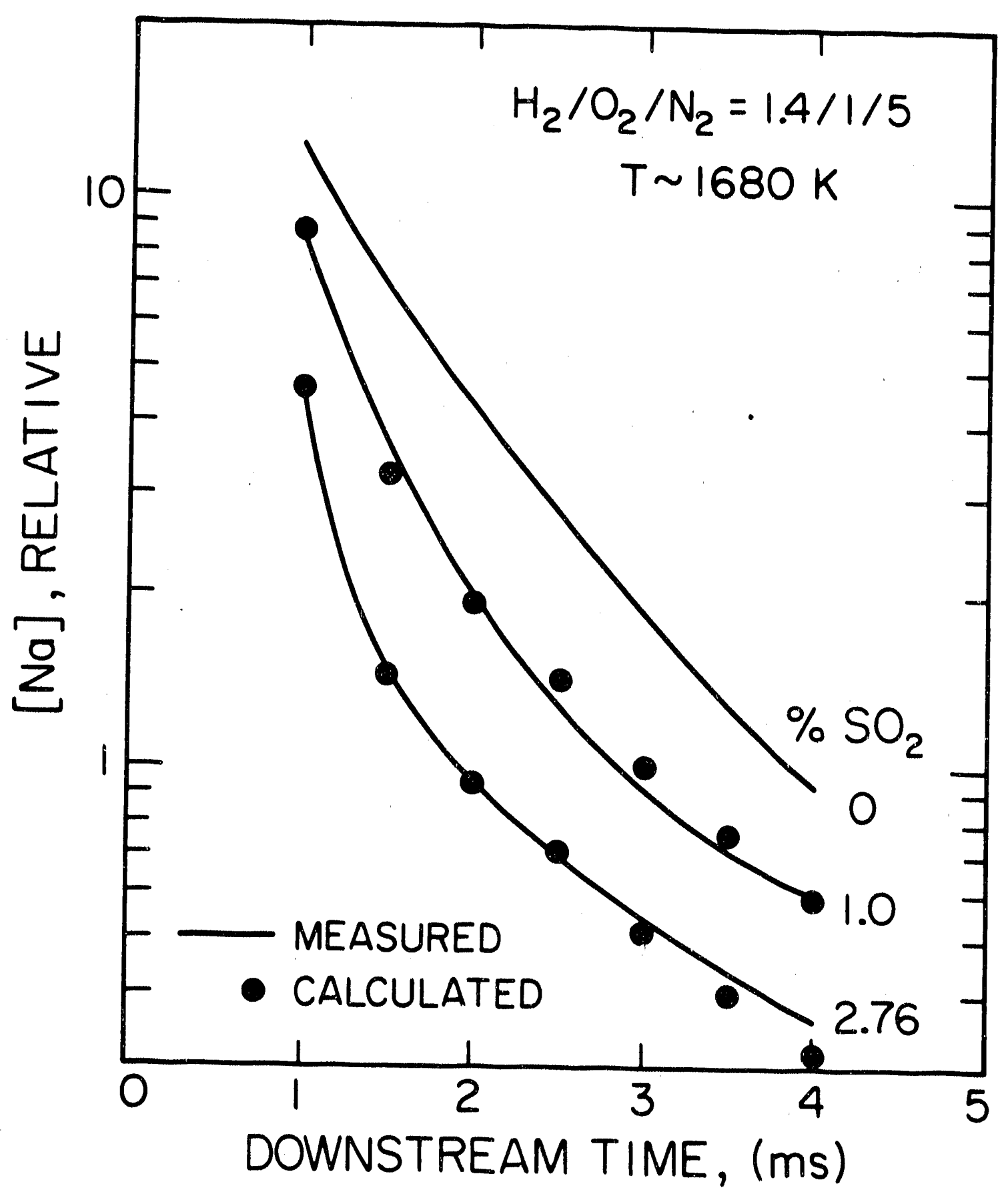

Figure 7. Comparison of measured and calculated sodium profiles in a lean $\mathrm{H}_{2} / \mathrm{O}_{2} / \mathrm{N}_{2}$ flame with varying amounts of $\mathrm{SO}_{2}$. 
addition of the $\mathrm{NaSO}_{2}$ chemistry to the oxidation model improved the fit of the model to all ten of the lean flames, confirming its presence and role. As previously noted, in these kinetic cycles optimal fits are most sensitive to unknown bond dissociation energies rather than rate constants. As a result, it is possible to derive a value for $\mathrm{D}_{0}^{\circ}\left(\mathrm{Na}-\mathrm{SO}_{2}\right)$ of $197 \pm 20$ $\mathrm{kJ} \mathrm{mol}{ }^{-1}$ for an assumed non-planar structure.

When the model was applied to the rich flame data, it was assumed initiaily that $\mathrm{NaOS}$ was the only significant sodium/sulfur product. Rather good agreement was obtained between experimental and calculated values of $(\mathrm{Na})$ except that the optimal value for $\mathrm{D}_{0}^{\circ}(\mathrm{Na}-\mathrm{OS})$ appeared to be $293 \mathrm{~kJ} \mathrm{~mol}^{-1}$. Obviously such a large value was unacceptable as it cannot be expected to exceed the $243 \mathrm{~kJ} \mathrm{~mol}^{-1}$ result determined for $\mathrm{NaO}_{2}{ }^{9,10}$. It was apparent that the only way to produce the required large steady state concentration of $\mathrm{NaOS}$, with such a simple model, was to minimize its thermal dissociation by artificially inflating the bond strength. Obviously, alternate production channels also were occurring. Considerations of the relative formation rates of the other sodium/sulfur compounds indicated that these also have to be playing a role. As a result, the model was enlarged to encompass their presence utilizing their respective bond strengths as listed in Table 2, together with that for $\mathrm{NaSO}_{2}$ established from the lean flame analysis. Under these conditions, but invoking the predicted bond strength of $\mathrm{NaOS}$, it is seen that $\mathrm{NaOS}$ remains the dominant rich flame product but with small contributions from $\mathrm{NaSO}_{2}, \mathrm{NaSH}, \mathrm{NaS}$, and $\mathrm{NaS}_{2}$. The agreement between model and experiment is indicated in Figure 8. In the absence of sulfur, most of the sodium is atomic in fuel rich flames. This results mainly from the high levels of $\mathrm{H}$ and $\mathrm{OH}$ which suppress molecular formation and reduce $\mathrm{NaOH}$ very effectively back to $\mathrm{Na}$. As a result, in this 


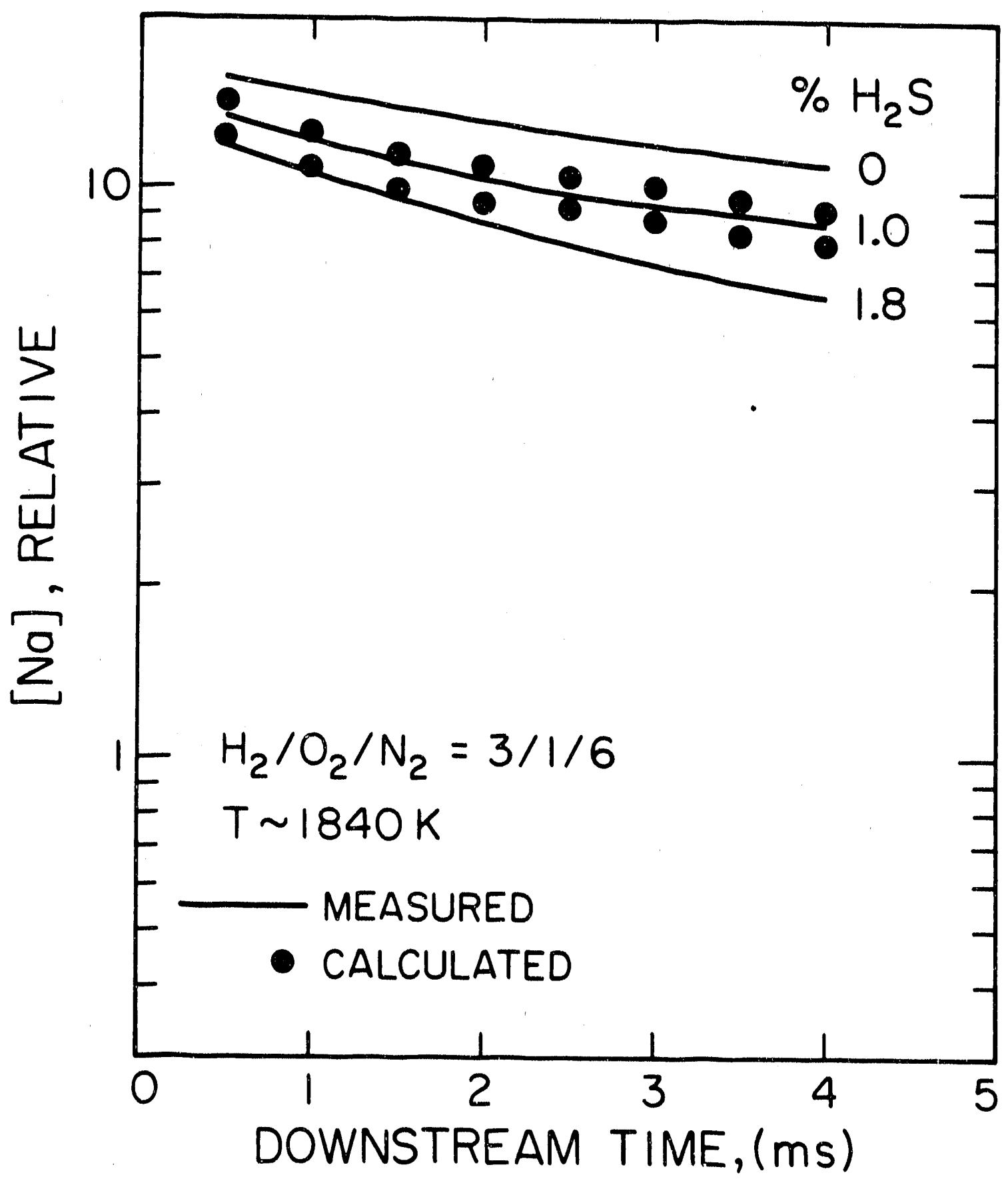

Figure 8. Comparison of measured and calculated sodium profiles in a rich $\mathrm{H}_{2} / \mathrm{O}_{2} / \mathrm{N}_{2}$ flame with varying amounts of $\mathrm{H}_{2} \mathrm{~S}$. 
case the enhanced sodium depletions noted in the presence of sulfur arise primarily from the formation of sodium/sulfur compounds and the essentially free sodium concentrations are insensitive to the radical level changes induced by the sulfur. The modeling indicates that a perturbation of the $\mathrm{NaOH} / \mathrm{Na}$ relative concentration ratios is very small and any $\mathrm{NaOS}$ or other sodium/sulfur compound converting to $\mathrm{NaOH}$ rapidly regenerates free $\mathrm{Na}$. Consequently, unlike lean conditions, where only a small steady state concentration of $\mathrm{NaSO}_{2}$ was produced, a more significant concentration of $\mathrm{NaOS}$ is established, roughly comparable to the observed sodium depletion. Typical profiles of the distributions of the sodium compounds are shown in Figures 9 and 10 for the same flames as Figures 3 and 4 , respectively. For the lean flame, Figure $9, \mathrm{NaOH}$ is the dominant oxidation product with $\mathrm{NaO}_{2}$ concentrations about a factor of four smaller. $\mathrm{Na}$ and $\mathrm{NaSO}_{2}$ become relatively minor components. For the rich flame in Figure 10, free atomic sodium is the dominant sodium form. $\mathrm{NaOS}$ is the major sodium molecular product followed by $\mathrm{NaOH}$. $\mathrm{NaOS}$ concentrations in the rich flames with $1 \% \mathrm{H}_{2} \mathrm{~S}$ ranged from 1 to $16 \%$ of the total sodium with the larger values occurring for the lower temperature and richer flames. $\mathrm{NaOH}$ values ranged from 1 to $17 \%$ with the higher values occurring at the higher temperatures and in the less rich flames. Although $\mathrm{NaOH}$ is thermodynamically much more stable than $\mathrm{NaOS}$, the formation of $\mathrm{NaOS}$ and its conversion to $\mathrm{NaOH}$ are kinetically controlled with the result that equilibrium overshoots of $\mathrm{NaOS}$ concentrations occur in the cooler rich flames. $\mathrm{NaSO}_{2} \mathrm{NaSH}, \mathrm{NaS}$, and $\mathrm{NaS}_{2}$ are each the order of $1 \%$ of the total sodium in these flames. However, due to the lack of sensitivity it is not possible to accurately partition the sodium among these relatively minor species. 


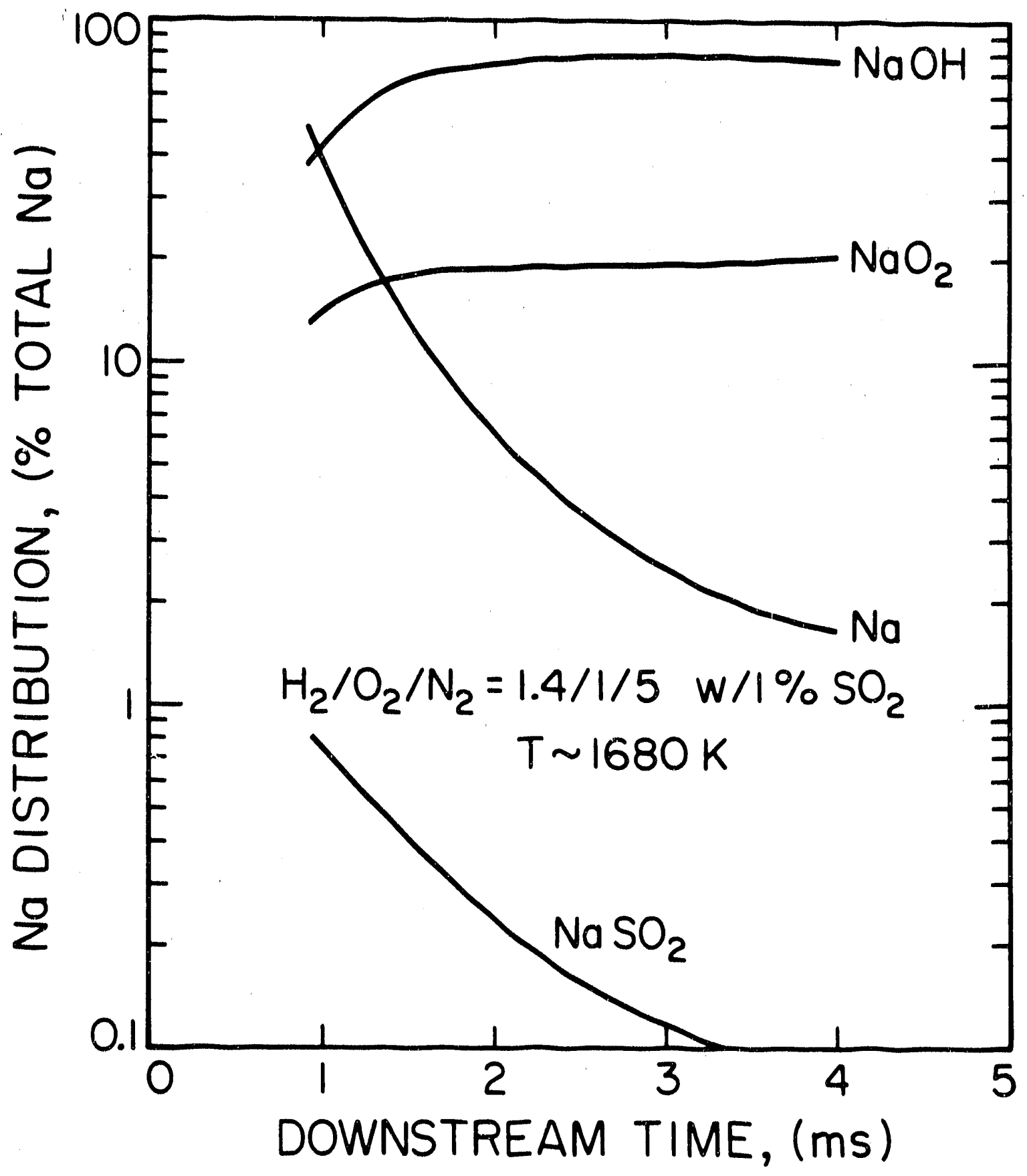

Figure 9. Calculated sodium compound relative distribution profiles in a lean $\mathrm{H}_{2} / \mathrm{O}_{2} / \mathrm{N}_{2}$ flame with added $\mathrm{SO}_{2}$. 


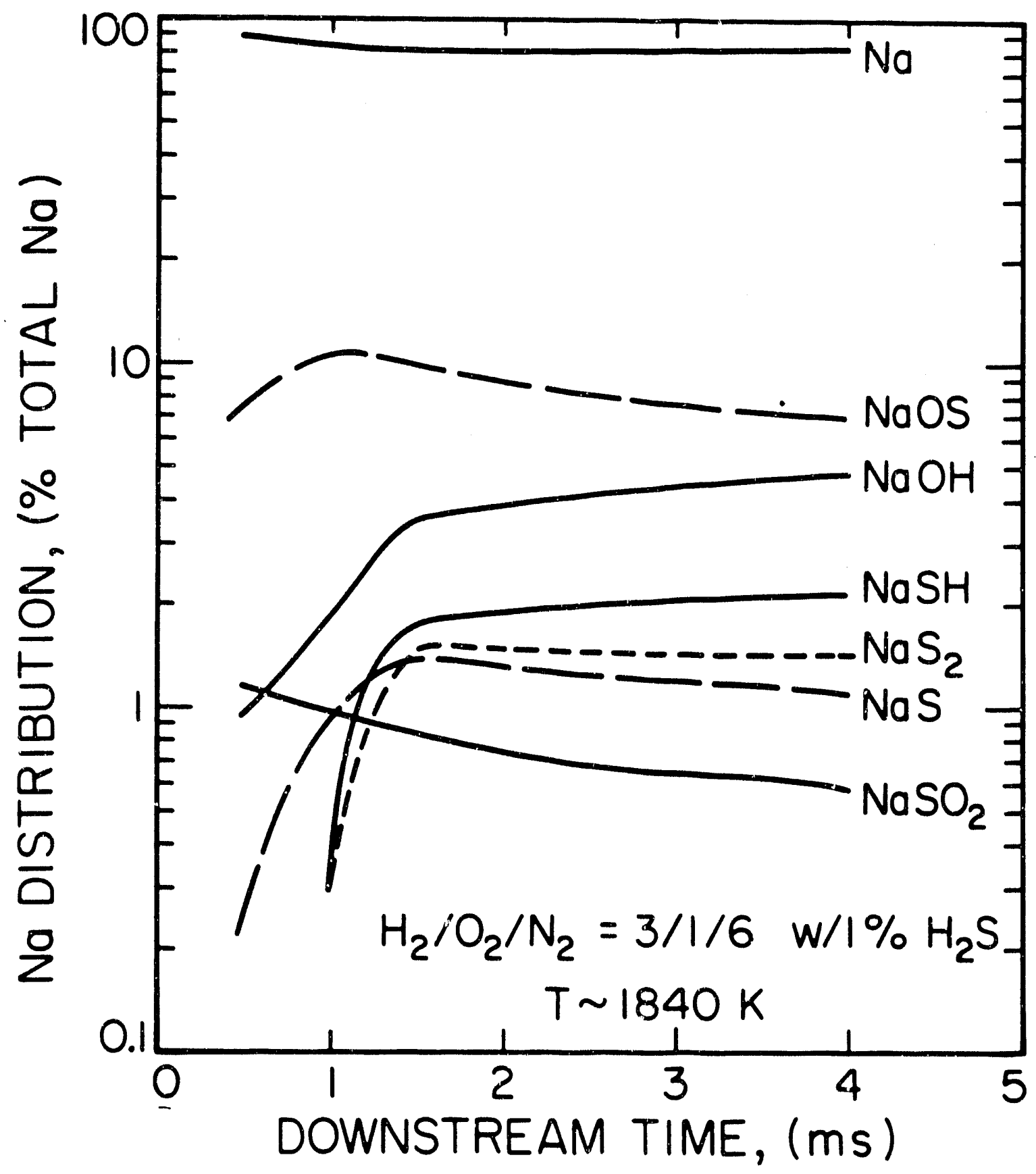

Figure 10. Calculated sodium compound relative distribution profiles in a rich $\mathrm{H}_{2} / \mathrm{O}_{2} / \mathrm{N}_{2}$ flame with added $\mathrm{H}_{2} \mathrm{~S}$. 
Preliminary measurements also have been made in a series of seven fuel rich $\mathrm{C}_{2} \mathrm{H}_{2}$ $/ \mathrm{O}_{2} / \mathrm{N}_{2}$ flames, soot-free, with equivalence ratios from 1.2 to 2.0 and temperatures ranging from 1800 to $2400 \mathrm{~K} .{ }^{49}$ Although sulfur produced very significant catalytically induced changes to the $\mathrm{H}$ and $\mathrm{OH}$ radical concentration levels, the effects on the concentrations of atomic sodium were very slight. This proved to be entirely as predicted by the rich $\mathrm{H}_{2}$ $/ \mathrm{O}_{2} / \mathrm{N}_{2}$ flame model. As is now quite apparent with the sodium flame oxidation kinetics, $^{12,13}$ this implies that the sodium/sulfur chemistry also is insensitive to the presence of flame carbon. Alkali flame chemistry appears to be independent of fuel type. As a result, the present work is equally pertinent to all fossil fueled flames.

\section{DISCUSSION}

We are now in a position to reassess the earlier sodium/sulfur investigations and draw conclusions concerning the question of sodium sulfate gas phase formation in combustion systems. In their studies, Fenimore ${ }^{6}$ and Durie et al. ${ }^{7}$ assumed their flames were at thern dynamic equilibrium. In the present work, measured $\mathrm{OH}$ concentrations were still significantly in excess of their equilibrium values at $4 \mathrm{~ms}$ downstream in rich and lean flames, with and without $1 \%$ added sulfur dopant. Nonequilibrium $\mathrm{OH}$ behavior increased with decreasing temperature below $2200 \mathrm{~K}$. More importantly, Fenimore in his lean flame analysis neglected the efficient $\mathrm{Na}+\mathrm{O}_{2}+\mathrm{M}$ reaction which is essential to understanding the sodium oxidation. ${ }^{9,10}$ Durie et al. assumed $\mathrm{SO}_{3}$ to be equilibrated. As indicated in this study, $\mathrm{SO}_{3}$ formation in flames is kinetically limited through the slow termolecular reaction(7) and can play no major role. Their lean $\mathrm{C}_{3} \mathrm{H}_{8} / \mathrm{O}_{2} / \mathrm{N}_{2}$ flame analysis was primarily based on Fenimore's $\mathrm{H}_{2}$ /Air flame data. In the absence of 
measured $\mathrm{OH}$ concentration profiles in both these studies it is difficult to see how they could achieve a correct kinetic description of this complex system. Consequently, no weight can be placed on the interpretation of their data. Their quoted equilibrium constants for reactions (1) to (3) imply values of $\mathrm{D}_{0}^{\circ}\left(\mathrm{Na}-\mathrm{SO}_{2}\right)=273, \mathrm{D}_{0}^{\circ}(\mathrm{Na}-\mathrm{S})=83$ and $\mathrm{D}_{0}^{\circ}\left(\mathrm{Na}-\mathrm{SO}_{3}\right)=164 \mathrm{~kJ} \mathrm{~mol}^{-1}$, which are totally inconsistent with the values in Table 2 and have no credibility.

The one firm value derived from the present study is $\mathrm{D}_{0}\left(\mathrm{Na}-\mathrm{SO}_{2}\right)=197 \pm 20 \mathrm{~kJ} \mathrm{~mol}^{-1}$. This appears to be consistent with a lower limit estimate of $\geq 190 \pm 15 \mathrm{~kJ} \mathrm{~mol}^{-1}$ recently assessed from a kinetic study of the $\mathrm{Na}+\mathrm{SO}_{2}+\mathrm{Ar}$ reaction. ${ }^{50}$ Their measured rate constant at $787 \mathrm{~K}$ indicates a very efficient process, about 10 -fold more so than for the reaction $\mathrm{Na}+\mathrm{O}_{2}+\mathrm{N}_{2}$. As indicated in Table 3, for the flame environment, we have in fact used a value 6-fold larger. In thie light of unknown temperature dependences and third body effects this appears to be satisfactorily consistent with this first direct experimental measure.

As mentioned earlier, Bencivenni et al. ${ }^{31}$ favored a planar structure for ground state $\mathrm{NaSO}_{2}$ whereas we have used a non-planar shape. The difference in symmetry for these two configurations makes our calculated equilibrium constant of formation one-half that for the planar structure. Increasing it two-fold would have an effect equivalent to an increase of $12 \mathrm{~kJ} \mathrm{~mol}^{-1}$ in our value for $\mathrm{D}_{0}^{\circ}\left(\mathrm{Na}-\mathrm{SO}_{2}\right)$. In their ab initio modeling, Ramondo and Bencivenni ${ }^{47}$ indicated a value for $\mathrm{D}_{0}^{\circ}\left(\mathrm{Na}-\mathrm{SO}_{3}\right)=254$ or $\mathrm{D}_{\text {ion }}^{\circ}\left(\mathrm{Na}^{+}-\mathrm{SO}_{2}^{-}\right)=643 \mathrm{~kJ} \mathrm{~mol}^{-1}$, values totally inconsistent with the lean flame modeling and the correlations of Figure 5. Such a value would result in a sharp overconsumption of sodium relative to that observed experimentally. In fact, the flames modeling becomes incompatible with bond 
strengths for $\mathrm{Na}-\mathrm{SO}_{2}$ much in excess of $197 \mathrm{~kJ} \mathrm{~mol}^{-1}$ for a nonplanar structure or $210 \mathrm{~kJ}$ $\mathrm{mol}^{-1}$ for a planar molecule. The thermal dissociation loss channel is pivotal in the modeling and is the reason for this great sensitivity to absolute bond energy value.

The situation in rich flames is more complex and although $\mathrm{NaOS}$ is the dominant new compound, small non-negligible contributions from $\mathrm{NaSO}_{2} \mathrm{NaSH}, \mathrm{NaS}$ and $\mathrm{NaS}_{2}$, are present. Using estimated values for their respective bond strengths, together with that derived herein for $\mathrm{NaSO}_{2}$, it can be shown that the observed effects are compatible with such values. However, the large numbers of adjustable parameters make it impossible to independently establish a firm measure of any of these.

The question of homogeneous gas phase $\mathrm{Na}_{2} \mathrm{SO}_{4}$ generation in flame gases has been a source of considerable confusion. In the present study, $\mathrm{Na}_{2} \mathrm{SO}_{4}$ cannot be a significant product because of the low sodium concentration which is less than $1 \mathrm{ppm}$. However, we can make some kinetic estimates of its formation which would be favored in the oxidizing atmosphere of lean flames. Reaction (15) is the only plausible process by which $\mathrm{Na}_{2} \mathrm{SO}_{4}$ might be generated directly

$$
\mathrm{NaSO}_{2}+\mathrm{NaO}_{2}+\mathrm{M}=\mathrm{Na}_{2} \mathrm{SO}_{4}+\mathrm{M}
$$

from species known to exist in these flames. It might also reflect a large termolecular rate constant of magnitude $4 \times 10^{-25} \mathrm{~T}^{-2} \mathrm{~cm}^{6}$ molecule $\mathrm{s}^{-2}$, as was found for the $\mathrm{Na}+\mathrm{O}_{2}+\mathrm{M}$ reaction. Using data of Figure 9 for the $\mathrm{H}_{2} / \mathrm{O}_{2} / \mathrm{N}_{2}=1.4 / 1 / 5$ flame with $1 \% \mathrm{SO}_{2}$ estimates for $\mathrm{Na}_{2} \mathrm{SO}_{4}(\mathrm{~g})$ formation have been made and are summarized in Table 4. For $(\mathrm{Na})_{\mathrm{T}}=100$ ppm at 100 ms downstream from the flame front the $\mathrm{Na}_{2} \mathrm{SO}_{4}$ concentration corresponds to about $0.1 \mathrm{ppm}$. The corresponding $\mathrm{Na}_{2} \mathrm{SO}_{4}$ dew point is about $1100 \mathrm{~K}$. This is with a value for $\mathrm{k}_{15}$ that is undoubtedly large. Reducing it lowers the $\mathrm{Na}_{2} \mathrm{SO}_{4}$ concentration and 
the dew point. Consequently, such a scheme illustrates that $\mathrm{Na}_{2} \mathrm{SO}_{4}$ formation would be far from equilibrium at $100 \mathrm{~ms}$ from the burner when $(\mathrm{Na})_{\mathrm{r}}$ is $100 \mathrm{ppm}$.

Table 4. $\mathrm{Na}_{2} \mathrm{SO}_{4}(\mathrm{~g})$ formation estimates for a $\mathrm{H}_{2} / \mathrm{O}_{2} / \mathrm{N}_{2}=1.4 / 1 / 5$ flame with $1 \% \mathrm{SO}_{2}$

\begin{tabular}{|c|c|c|c|c|}
\hline \multirow[t]{3}{*}{$(\mathrm{Na})_{T}, \mathrm{ppm}$} & \multicolumn{4}{|c|}{$\left(\mathrm{Na}_{2} \mathrm{SO}_{4}\right), \mathrm{ppm}$} \\
\hline & \multicolumn{4}{|c|}{ Time, (ms) } \\
\hline & 1 & 10 & 100 & $\infty$ (Equilibrium) \\
\hline 1 & $1.4 \times 10^{-3}$ & $6.3 \times 10^{-6}$ & $1.0 \times 10^{-5}$ & $2.1 \times 10^{-4}$ \\
\hline 10 & $1.4 \times 10^{-4}$ & $6.3 \times 10^{-4}$ & $1.0 \times 10^{-3}$ & $2.1 \times 10^{-2}$ \\
\hline 100 & $1.4 \times 10^{-2}$ & $6.3 \times 10^{-2}$ & $1.0 \times 10^{-1}$ & 1.9 \\
\hline
\end{tabular}

Alternatively, bimolecular reaction paths for $\mathrm{Na}_{2} \mathrm{SO}_{4}$ formation might be considered, for example reaction (16) followed by reactions $(17,18)$.

$$
\begin{array}{r}
\mathrm{NaSO}_{2}+\mathrm{NaOH}=\mathrm{Na}_{2} \mathrm{SO}_{3}+\mathrm{H} \\
\mathrm{Na}_{2} \mathrm{SO}_{3}+\mathrm{O}_{2}=\mathrm{Na}_{2} \mathrm{SO}_{4}+\mathrm{O} \\
\mathrm{Na}_{2} \mathrm{SO}_{3}+\mathrm{OH}=\mathrm{Na}_{2} \mathrm{SO}_{4}+\mathrm{H}
\end{array}
$$

$\Delta \mathrm{H}$ for reaction (16) can be estimated to be at least $160 \mathrm{~kJ} \mathrm{~mol}^{-1}$. Using a gas kinetic rate constant for reaction (16) and assuming reactions $(17,18)$ quickly convert all $\mathrm{Na}_{2} \mathrm{SO}_{3}$ to $\mathrm{Na}_{2} \mathrm{SO}_{4}$, a value is obtained for $\left(\mathrm{Na}_{2} \mathrm{SO}_{4}\right)$ of about $0.003 \mathrm{ppm}$ for $(\mathrm{Na})_{\mathrm{T}}=100 \mathrm{ppm}$ at 100 ms. The three body process is seen to be much faster. Consequently, our present knowledge of the distribution of sodium over its molecular forms clearly indicates that $\mathrm{Na}_{2} \mathrm{SO}_{4}$ cannot possibly be a gas phase component under commonly encountered flame conditions. It must result from heterogeneous surface catalyzed combinations of simpler molecules that finally realize the $\mathrm{Na}_{2} \mathrm{SO}_{4}$ structural form.

In light of our results concerning the apparent minor importance of sodium/sulfur 
compounds in flames it is appropriate to examine the quantitative results of two detailed $\mathrm{Na}_{2} \mathrm{SO}_{4}$ deposition studies in an attempt to speculate which gas phase species may be controlling the heterogeneous process.

In deveioping an in situ, Raman scattering diagnostic of flame deposits, McCarty and Anderson ${ }^{51}$ elegantly demonstrated the nature of the deposition from sodium/sulfur seeded methane flames. In an oxygen rich flame (equivalence ratio, $\phi=0.98$ ) the only material in the deposit was $\mathrm{Na}_{2} \mathrm{SO}_{4}$. However, under fuel rich conditions, $\mathrm{Na}_{2} \mathrm{CO}_{3}$ was the sole ingredient and at stoichiometry both could be formed. This confirmed an earlier experimentally more difficult study of Durie et al..$^{52}$ in which collected samples were withdrawn and analyzed by wet chemical techniques. The only difference was that these results also indicated the presence of $\mathrm{Na}_{2} \mathrm{SO}_{3}$ in the early part of slightly fuel rich flames which was not evident in the downstream data of McCarty and Anderson. ${ }^{51}$ The two studies were experimentally very different, the earlier using $\mathrm{C}_{3} \mathrm{H}_{8} / \mathrm{Air}(\phi=0.91$ to 1.7 ) with $1 \% \mathrm{SO}_{2}$ and a significant seeding level of fine particles of sodium oxalate $(0.5-0.8 \%$ by weight of $\mathrm{Na}$ ). Temperatures spanned 1900 to $2300 \mathrm{~K}$ with a collection probe maintained at $723 \mathrm{~K}$ and operating in the first $8 \mathrm{~cm}$ downstream region. The more recent work burned $\mathrm{CH}_{4} / \mathrm{O}_{2} / \mathrm{N}_{2}(\phi=0.98 \cdot 1.18)$ and solely added coarse particles of $\mathrm{Na}_{2} \mathrm{SO}_{4}(\leq 105 \mu \mathrm{m}$ sizes). Temperatures were in the 1800 to $1950 \mathrm{~K}$ range, the deposition surface was at $825 \mathrm{~K}$, and data collected much further downstream at $27 \mathrm{~cm}$ from the reaction zone. Even though it might not have been expected to realize complete salt vaporization, particularly in the latter case ${ }^{53,4}$, they did report an absence of flame particles downstream. It is well established for alkali salts, including $\mathrm{Na}_{2} \mathrm{SO}_{4}$, that once vaporized, dissociation is rapid and they behave as equivalent sources of alkali.55 It is on this very 
basic point that the flame spectral analyses method for alkalis is founded.

In fuel rich flames it is apparent that benign $\mathrm{Na}_{2} \mathrm{CO}_{3}$ deposits are dominant. We now know that such flames contain $\mathrm{SO}_{2}, \mathrm{SO}, \mathrm{S}_{2}, \mathrm{H}_{2} \mathrm{~S}$ and $\mathrm{SH}$ together with $\mathrm{Na}, \mathrm{NaOS}$ and $\mathrm{NaOH}$ in an environment rich in $\mathrm{H}$ and $\mathrm{OH}$ radicals. On the other hand, in lean flames which produce $\mathrm{Na}_{2} \mathrm{SO}_{4}$ deposits, only $\mathrm{SO}_{2}$ is a dominant sulfur species, with sodium being distributed primarily between $\mathrm{NaOH}$ and $\mathrm{NaO}_{2}$, and concentrations of $\mathrm{NaSO}_{2}$ remaining very small. $\mathrm{OH}$ is the controlling flame radical. A comparison of these two extreme flame stoichiometries shows under fuel rich conditions, in spite of the presence of numerous species, that these are not able to promote $\mathrm{Na}_{2} \mathrm{SO}_{4}$ formation. As to whether this results from a missing ingredient or is a consequence of rapid destruction fluxes has to be seen. In lean flames, the insignificant concentrations of $\mathrm{NaSO}_{2}$ appear to be too small to account for the heterogeneous $\mathrm{Na}_{2} \mathrm{SO}_{4}$ formation which can occur in spite of significant $\mathrm{OH}$ radical concentrations. As a result, this raises the speculation that the combination of $\mathrm{NaO}_{2}$ in a significant environment of $\mathrm{SO}_{2}$ may hold the answer to $\mathrm{Na}_{2} \mathrm{SO}_{4}$ formation, the two reacting in some manner on the cooler surface. This is consistent with current observations but requires further deatailed studies.

The fact that $\mathrm{Na}_{2} \mathrm{CO}_{3}$ deposits appear under fuel rich flame conditions also is a very intriguing observation and might indicate the need for conditions in which significant concentrations of free atomic sodium exist. This is without doubt likewise a heterogeneous formation process especially as alkali carbonates are known to be extremely unstable in flames. However, in the gas phase at room temperatures, Ager and Howard ${ }^{56}$ have noted the very efficient termolecular recombination of $\mathrm{NaO}$ with $\mathrm{CO}_{2}$ to produce $\mathrm{NaCO}_{3}$. The possibility that similar recombinations may occur between $\mathrm{Na}$ or 
$\mathrm{NaOH}$ and $\mathrm{CO}_{2}$ on cooler flame immersed surfaces is worthy of a more detailed study.

\section{CONCLUSIONS}

Sodium/sulfur chemistry has been experimentally monitored and modeled in a series of rich and lean $\mathrm{H}_{2} / \mathrm{O}_{2} \mathrm{~N}_{2}$ flames. It was found that the simple equilibria previously suggested in earlier studies ${ }^{6,7}$ cannot account for the behavior exhibited with the present more extensive data base and that their analyses are invalid. Kinetic modeling has been conducted and, as is often the case in flames, one sodium/sulfur product dominates. To a good approximation this is the situation in both the rich and lean flames. $\mathrm{NaSO}_{2}$ appears to be the only sodium/sulfur product in the lean $\mathrm{H}_{2} / \mathrm{O}_{2} / \mathrm{N}_{2}$ flames. $\mathrm{NaOS}$ is dominant in the rich flames, but in this case is accompanied by smaller contributions from $\mathrm{NaSO}_{2}, \mathrm{NaSH}, \mathrm{NaS}$, and $\mathrm{NaS}_{2}$. Data obtained with a series of fuel rich acetylene flames are explained very adequately by the present model, indicating that the same conclusions seem valid for fossil fuel flames. A value for the bond dissociation energy of $\mathrm{D}_{0}^{\circ}\left(\mathrm{Na}-\mathrm{SO}_{2}\right)$ of $197 \pm 20 \mathrm{~kJ} \mathrm{~mol}^{-1}$ has been derived in the kinetic modeling of the lean flame data assuming a non-planar structure. If this has a planar shape, as more recently suggested, ${ }^{31}$ this will have the effect of increasing the magnitude by about $12 \mathrm{~kJ} \mathrm{~mol}^{-1}$.

Some estimates for $\mathrm{Na}_{2} \mathrm{SO}_{4}(\mathrm{~g})$ formation rates have been made for some of the experimental lean flame conditions of the present study. Using upper limit estimates for rate parameters, the results predict it would require sodium concentrations of about 100 ppm before significant disodium products or $\mathrm{Na}_{2} \mathrm{SO}_{4}$ might form. $\mathrm{Na}_{2} \mathrm{SO}_{4}(\mathrm{~g})$ is not a particularly stable molecule in a flame environment. ${ }^{5557}$ Moreover, kinetically there appears to be insufficient time for its formation in burnt combustion gases. As a result, 
high temperature $\mathrm{Na}_{2} \mathrm{SO}_{4}$ induced corrosion in combustion gas flows must proceed through heterogeneous chemical formation of $\mathrm{Na}_{2} \mathrm{SO}_{4}$ on surfaces. A comparison of known flame compositions with reported deposition characteristics raises the speculation as to whether it is the combination of $\mathrm{NaO}_{2}$ and $\mathrm{SO}_{2}$ in lean flame conditions that constitute the pivotal ingredients for this surface induced $\mathrm{Na}_{2} \mathrm{SO}_{4}$ formation.

Acknowledgment

The support of this work by the Department of Energy, Morgantown Energy Technology Center, Morgantown WV, under Grant DE-FG21-86MC23135 is gratefully acknowledged. 


\section{REFERENCES}

1. W.T. Reid, R.C. Corey, and B.J. Cross, Trans. Amer. Soc. Mech. Eng. 67, 279 (1945); R.C. Corey, B.J. Cross, and W.T. Reid, ibid., 289.

2. E.L. Simons, G.V. Browning, and H.A. Liebhafsky, Corrosion 11, 505t (1955).

3. M.A. de Crescente and N.S. Bornstein, Corrosion 24, 127 (1968).

4. G.C. Fryburg, R.A. Miller, C.A. Stearns, and F.J. Kohl, in High Temperature Metal Halide Chemistry, D.L. Hildenbrand and D.D. Cubicciotti, Editors, p. 468, The Electrochemical Society Softbound Proceedings Volume 78-1, Princeton NJ (1978); also NASA TM-73794 (1977).

5. D.E. Rosner, B.-K. Chen, G.C. Fryburg, and F.J. Kohl, Combust. Sci. Technol. 20, 87 (1979).

6. C.P. Fenimore, Symp. (Int.) on Combustion 14, 955 (1973).

7. R.A. Durie, G.M. Johnson, and M.Y. Smith, Symp. (Int.) on Combustion 15, 1123 (1974).

8. C.H. Muller III, K. Schofield, M. Steinberg, and H.P. Broida, Symp. (Int.) on Combustion 17, 867 (1978).

9. A.J. Hynes, M. Steinberg, and K. Schofield, J. Chem. Phys. 80, 2585 (1984).

10. M. Steinberg and K. Schofield, "The High Temperature Chemistry and Thermodynamics of Alkali Metals (Lithium, Sodium, Potassium) in Oxygen Rich Flames," Presented at the Fall Joint Meeting of the Western States and Japanese Sections of the Combustion Institute, Paper 3A-042, Honolulu HI, November (1987).

11. M.R. Zachariah and O.I. Smith, Combust. Flame 69, 125 (1987).

12. M.G. Kasparov, A.V. Mokhov, and A.P. Nefedov, High Temp. USSR 26, 463 (1988).

13. M. Slack, J.W. Cox, A. Grillo, R. Ryan, and O. Smith, Combust. Flame 77, 311 (1989).

14. C.P. Fenimore and G.W. Jones, J. Phys. Chem. 69, 3592 (1965).

15. R.A. Durie, G.M. Johnson, and M.Y. Smith, Combust. Flame 17, 197 (1971). 
16. A.S. Kallend, Combust. Flame 19, 227 (1972).

17. D.C. Astholz, K. Glanzer, and J. Troe, J. Chem. Phys. 70, 2409 (1979).

18. O.I. Smith, S. Tseregounis, and S.-N. Wang, Int. J. Chem. Kinet. 14, 679 (1982).

19. D. Husain and J.M.C. Plane, J. Chem. Soc., Faraday Trans. II 78, 163 (1982).

20. J.A. Silver, M.S. Zahniser, A.C. Stanton, and C.E. Kolb, Symp. (Int.) on Combustion 20, 605 (1984).

21. D. Husain, P. Marshall, and J.M.C. Plane, J. Chem. Soc. Faraday Trans. II 81, 301 (1985).

22. D. Husain, P. Marshall, and J.M.C. Plane, J. Photochem. 32, 1 (1986).

23. J.M.C. Plane and B. Rajasekhar, J. Phys. Chem. 93, 3135 (1989).

24. P. Marshall, A.S. Narayan, and A. Fontijn, J. Phys. Chem. 94, 2998 (1990).

25. P.J. Padley and T.M. Sugden, Proc. Roy. Soc. Lond. Ser. A 248, 248 (1958).

26. M.B. Denton and D.B. Swartz, Rev. Sci. Instrum. 45, 81 (1974).

27. K. Schofield and M. Steinberg, Opt. Eng. 20, 501 (1981).

28. C.H. Muller III, K. Schofield, and M. Steinberg, ACS Symp. Series 134, 103 (1980).

29. CRC Handbook of Chemistry and Physics, D.R. Lide, ed., 71st edn., CRC Press, Inc., Boca Raton FL (1990).

30. F.J. Adrian, E.L. Cochran, and V.A. Bowers, J. Chem. Phys. 59, 56 (1973).

31. L. Bencivenni, F. Ramondo, R. Teghil, and M. Pelino, Inorg. Chim. Acta 121, 207 (1986).

32. B.J. McBride and S. Gordon, 'Fortran IV Program for Calculation of Thermodynamic Data," NAS\ TN D-4097, August, 1967 (Updated 1983 version).

33. S.R. Langhoff, C.W. Bauschlicher, Jr., and H. Partridge, in Comparison of ab Initio Quantum Chemistry with Experiment for Small Molecules: The State of the Art, R.J. Bartlett, editor, p., 357, Reidel Publishing Company (1985).

34. H. Partridge, S.R. Langhoff, and C.W. Bauschlicher, Jr., J. Chem. Phys. 88, 6431 (1988). 
35. M. Farber, R.D. Srivastava, and J.W. Moyer, High Temp. Science 16, 153 (1983).

36. J.A. Pappas, J. Am. Chem. Soc. 100, 6023 (1978).

37. M. Gruebele, M. Polak, and R.J. Saykally, J. Chem. Phys. 86, 1698 (1987).

38. R.H. Lamoreaux and D.L.Hildebrand, J. Phys. Chem. Ref. Data 13, 151 (1984).

39. M.W. Chase, Jr., C.A. Davies, J.R. Downey, Jr., D.J. Frurip, R.A. McDonald, anc A.N. Syverud, J. Phys. Chem. Ref. Data 14, Supplement 1 (1985).

40. G. Herzberg, Molecular Spectra and Molecular Structure. II. Infrared and Raman Spectra of Polyatomic Molecules, pp. 173-174, Van Nostrand Company, Inc., New York (1545).

41. L. Andrews, J. Phys. Chem. 73, 3922 (1969).

42. R.R. Smardzewski and L. Andrews, J. Chem. Phys. 57, 1327 (1972).

43. L. Andrews, J.-T. Hwang, and C. Trindle, J. Phys. Chem. 77, 1065 (1973).

44. K.P. Huber and G. Herzberg, Molecular Spectra and Molecular Structure. IV. Constants of Diatomic Molecules, Van Nostrand Rheinhold Company (1979).

45. S. Jin and H.F. Schaeffer III, J. Chem Phys. 93, 1799 (1990).

46. D.E. Milligan and M.E. Jacox, J. Chem. Phys. 55, 1003 (1971).

47. F. Ramondo and L. Bencivenni, Mol. Phys. 67, 707 (1989).

48. D.M. Stanbury, T.A. Holme, Z.H. Kafafi, and J.L. Margrave, Chem. Phys. Lett. 129, 181 (1986).

49. K. Schofield and M. Steinberg, "The Chemical Kinetic Nature of $\mathrm{CH}$ and $\mathrm{C}_{2}$ Radicals in Fuel Rich Acetylene Flames," Presented at the Fall Meeting of the Western States Section of the Combustion Institute, Paper WSS/CI 88-90, Dana Point CA, October (1988).

50. Y. Shi and P. Marshall, J. Phys. Chem. 95 (1991), in press.

51. K.F. McCarty and R.J. Anderson, Combust. Sci. Technol. 54, 51 (1987).

52. R.A. Durie, J.W. Milne, and M.Y. Smith, Combust. Flame 30, 221 (1977).

53. G.M. Hieftje, R.M. Miller, Y. Pak, and E.P. Wittig, Anal. Chem. 59, 2861 (1987). 
54. E.M. Bulewicz, E. Janicka, S. Kandefer, and B. Kucnerowicz-Polak, 'The Decomposition of $\mathrm{NaHCO}_{3}$ Particles in Flames," Abstract Presented at the 23rd International Symposium on Combustion, Orleans, France, July, 1990.

55. C.T.J. Alkemade, T. Hollander, W. Snelleman and P.J.T. Zeegers, Metal Vapors in Flames, Pergamon Press, Oxford U.K. (1982).

56. J.W. Ager III and C.J. Howard, Geophys. Res. Lett. 13, 1395 (1986).

57. K.H. Lau, R.D. Brittain, R.H. Lamoreaux and D.L. Hildenbrand, J. Electrochem. Soc 132, 3041 (1985). 


\section{PRESENTATIONS AND PUBLICATIONS}

\section{PRESENTATIONS}

1. "The Chemistry of Sodium with Sulfur in Flames," Paper Presented at the Symposium on Ash Deposition: Mineral Matter Transformations During Combustion Organized at the 197th National Meeting of the American Chemical Society, Held at Dallas TX, April 9-14, 1989.

2. "The Chemistry of Sodium with Sulfur in Flames," Poster Paper Presented at the 23rd International Symposium on Combustion, Held at Orleans, France, July 22-27, 1990.

\section{PUBLICATIONS}

1. M. Steinberg and K. Schofield, "The Chemistry of Sodium with Sulfur in Flames," Prog. Energy Combust. Sci. 16, 311-317 (1990).

2. K. Schofield and M. Steinberg, "Sodium/Sulfur Chemical Behavior in Fuel Rich and Lean Flames," J. Phys. Chem., Submitted for Publication, February 1991. 